\title{
Integrating Behavioural Aspects in Energy System Modelling-A Review
}

\author{
David Huckebrink ${ }^{+}\left(\mathbb{D}\right.$ and Valentin Bertsch ${ }^{*}+\mathbb{+}$ \\ Energy Systems and Energy Economics, Ruhr-University Bochum, 44801 Bochum, Germany; \\ david.huckebrink@ee.rub.de \\ * Correspondence: valentin.bertsch@ee.rub.de; Tel.: +49-234-32-26357 \\ + These authors contributed equally to this work.
}

Citation: Huckebrink, D.; Bertsch, V. Integrating Behavioural Aspects in Energy System Modelling-A Review. Energies 2021, 14, 4579. https://doi.org/10.3390/en14154579

Academic Editor: Carlos Henggeler Antunes

Received: 15 June 2021

Accepted: 23 July 2021

Published: 28 July 2021

Publisher's Note: MDPI stays neutral with regard to jurisdictional claims in published maps and institutional affiliations.

Copyright: (c) 2021 by the authors. Licensee MDPI, Basel, Switzerland. This article is an open access article distributed under the terms and conditions of the Creative Commons Attribution (CC BY) license (https:// creativecommons.org/licenses/by/ $4.0 /)$.

\begin{abstract}
Many countries worldwide have adopted policies to support the expansion of renewable energy sources aimed at reducing greenhouse gas emissions, combating climate change, and, more generally, establishing a globally sustainable energy system. As a result, energy systems around the world are undergoing a process of fundamental change and transformation that goes far beyond the technological dimension. While energy system models have been developed and used for several decades to support decision makers in governments and companies, these models usually focus on the techno-economic dimension, whereas they fall short in addressing and considering behavioural and societal aspects of decisions related to technology acceptance, adoption, and use. In fact, it is often the societal dimension that comes with the greatest challenges and barriers when it comes to making such a socio-technical transformation happen in reality. This paper therefore provides an overview of state-of-the-art energy system models on the one hand and research studying behavioural aspects in the energy sector on the other hand. We find that these are two well-developed fields of research but that they have not yet been integrated sufficiently well to provide answers to the many questions arising in the context of complex socio-technical transformation processes of energy systems. While some promising approaches integrating these two fields can be identified, the total number is very limited. Based on our findings, research gaps and potentials for improvement of both energy system models and behavioural studies are derived. We conclude that a stronger collaboration across disciplines is required.
\end{abstract}

Keywords: sustainable energy system; energy system transformation; energy system model; consumer behaviour; societal acceptance; technology adoption and use

\section{Introduction}

In order to keep the consequences of anthropogenic global climate change within boundaries, the goal of the Paris Agreement is to limit the average temperature increase compared to pre-industrial levels to well below $2{ }^{\circ} \mathrm{C}$ [1]. Being mainly driven by greenhouse gas (GHG) emissions, the predominant measure to achieve this goal lies in emission reduction. In this regard, changes related to people's behaviour and lifestyle can enable significant reductions, since all actions and decisions of humans, reaching as far as changing dietary behaviour, influence energy use and therefore have direct or indirect impacts on the energy system and on the environment $[2,3]$.

Currently, the main focus with respect to reducing emissions lies on energy systems, since they are responsible for a large part of global emissions. In order to adequately assess these and to inform policymakers with regard to how emissions can be reduced costefficiently, energy system models (ESM) have been developed and used for several decades. These models have historically focused on the electricity sector, depicting generation, transmission and storage technologies in terms of their technological capabilities and cost structures. More recent enhancements encompass other sectors such as heat and gas 
and allow for conversion between these energy carriers. Solutions of ESMs are systems that meet energy demand optimally under a predefined objective function, typically the minimisation of cost.

While energy system models provide a valuable basis for decision makers in governments or companies; however, these models fall short in addressing and considering humans and the complexity of their behaviour. Accounting for this is seen as one of four major categories with respect to which ESMs need to be improved so as to be able to address "twenty-first century energy challenges" [4]. Yet, the integration of human behaviour in models is often marginalised to technology adoption and diffusion rates. While still relying on cost-minimisation, models implicitly assume that humans act in a way that would be optimal from a system-cost perspective. However, this is a poor representation of preferences and purchasing decisions [5]. Humans do not even act in a cost-minimising manner for their own self-interest. An example of this can be found in the field of mobility. Considering the total cost of ownership (TCO) per kilometre travelled, the most affordable travel modes (public transit, active travel and small, efficient cars) have the lowest market shares in many countries [6]. A better understanding of users is therefore crucial in order to assess the likelihood of scenarios, since the quantity of adopters, their preferences towards certain traits of a technology, and their interactions with it remain largely unknown [6]. While adoption rates and market shares are important, the active use of a technology is what ultimately determines energy demand. For instance, depending on the consumers' interaction with EV services, energy demand for individual transport might be cut in half, or increase by a factor of two in the future [7].

Although the fact that energy is omnipresent in the lives of humans is largely neglected in the world of energy system modelling [8,9], there is a growing body of literature concerned with societal and behavioural aspects of the energy transition. In particular, there is a wealth of research studying the public acceptance of technologies generating electricity from variable renewable energy sources (vRES). Low public acceptance is seen as an obstacle to installing such low-carbon technologies required for reaching emission reduction targets [10]. Additionally, carbon capture and storage (CCS) technologies are increasingly seen as necessary for scenarios compliant with the goals of the Paris Agreement. Therefore, societal acceptance in addition to affordability and technical as well as environmental criteria must be met well before 2050, at which point the required technologies already need to be in operation [3]. This imposes a challenge since acceptance levels for these technologies are currently rather low, implying that a substantial behavioural or attitudinal change is required within a short period of time. However, changing behaviour is far from trivial, since behaviour is interwoven in and greatly affected by social, cultural and institutional contexts [2].

Human behaviour can ultimately become a driver of or a barrier to the energy transition. Despite this large range of options and the potential implications for the future energy system, little has been done to adequately depict human behaviour in ESMs. This has so far limited the ability of ESMs to produce more robust projections or policy evaluations [5]. ESMs should therefore adopt a broader perspective, since the construction and operation of technical infrastructure depends on markets, institutions and consumer behaviour [11,12].

\subsection{Scope of Work}

This paper seeks to provide an overview of energy system modelling and analysis techniques that are capable of considering behavioural and societal aspects of decision-making in the energy sector so as to improve the capabilities of energy system models to produce more robust results and inform policymakers. We focus on technologies and services that are deemed to play a key role in the future energy system based on the prevailing literature: At utility scale these are large scale vRES power plants and transmission lines [13,14]. At the residential scale these are EVs [15] and micro-generation technologies such as solar photovoltaics (PV) and climate-neutral appliances for residential heating such as heat pumps [13]. In addition to these technologies, we consider energy services, by which we 
mean various tariff models (including, e.g., dynamic pricing) offered to consumers that provide incentives for responsive demand, but also mobility-related services in the context of car sharing or multi-modal transport options.

Beyond defining the technologies of particular interest, it is important to define the categories of behavioural aspects that this paper focuses on, namely the acceptance, adoption and use of a technology or service. Acceptance of a technology partly determines the adoption [16], which is mandatory for its usage. In other words, a certain degree of acceptance must be held to consider adoption (buying) said technology and only then can the technology be used. Thus, these categories can be seen as successive steps that must be taken towards the use of any new energy technology. Each of these stages can largely influence the development of supply (e.g., the amount of electricity produced by wind power) and demand (e.g., the final energy from EVs) in energy systems. Furthermore, adopting one technology can unlock further technologies to be accepted and adopted. For example, the adoption and use of EVs allows for the acceptance and adoption of smart charging, which has been analysed in [16-18]. This also illustrates that these categories are interdependent as acceptance and adoption of one technology determine the use of a different technology. We therefore distinguish between and analyse the literature dealing with the behavioural aspects of acceptance, adoption and use.

Note that not all technologies and services are affected similarly by the categories of human behaviour. For instance, electric vehicles can be accepted, adopted and used by an individual, which is not the case for transmission or large-scale vRES power plants. From a consumer perspective, such technologies can only be accepted or rejected. Yet, they are of course being used, but usage is not actively intended by consumers but by the corresponding technology operators. To illustrate this concept, the behavioural aspects (acceptance, adoption and use) are used as one of three dimensions for our research. The next dimension is, as described above, the set of technologies and services of interest (see Figure 1). Lastly, we investigate the modelling approaches used to incorporate the behavioural aspects as a third dimension.

Behavioral aspects

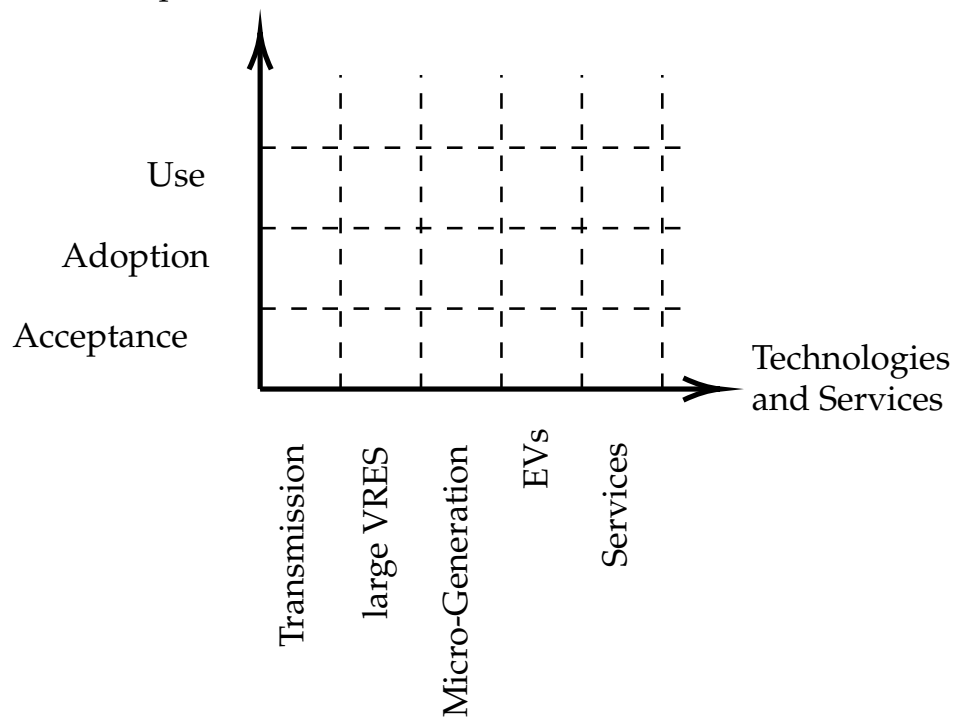

Figure 1. Behavioural aspects and technologies considered in this study.

In the following, we briefly define the terms of acceptance, adoption and use as used in this paper.

\subsubsection{Acceptance}

Even though a consensus appears to exist that missing societal acceptance can be a barrier to the required energy transformation regarding grid and renewable energy expansion, 
a consistent definition of acceptance does not yet exist $[19,20]$. On the contrary, different definitions and understandings can be found across and even within disciplines [21]. We therefore present prominent categorisations and outline intersections therein.

Wüstenhagen et al. [20] define three dimensions of acceptance: socio-political, community and market acceptance. Socio-political acceptance relates to the public, key stakeholders and policymakers. Acceptance at the community level refers to the local siting of renewable energy projects and the attitude of residents affected, whereas market acceptance refers to the process of adopting a certain technology. The first two categories coincide with definitions of Emmerich et al. [19] who define "general acceptance" as attitudes towards a technology in general and "local acceptance" as attitudes of residents towards a technology, which is to be located nearby. Bertsch et al. [22] also support this understanding of acceptance on a general level, where they extend the scope of acceptance to include products and policies in addition to technologies and differentiate between active and passive behaviour. This view is in line with a definition of Wolsink [23], who argues that the acceptance of renewable energy innovation entails many decision-making processes either promoting or counteracting against new technologies. A similar two-dimensional model has been developed by Schweizer-Ries [24] consisting of an activity and a valuation axis, with activity ranging from passive to active and valuation ranging from negative to positive. Thus, the model yields four quadrants categorising an individual's relation towards a technology. While this is not explicitly proposed by [24], the distinction between socio-political, community and market levels could be added as a third axis. We chose the model of Schweizer-Ries [24] for our work, since it describes a common understanding and allows for visual interpretation. It has thus been generalised to accommodate adoption on its area rather than being one end of the valuation spectrum, allowing for a path to be drawn on this diagram representing the journey of an individual towards the use of or the resistance against a new technology. The positive path, displayed in Figure 2 is laid out as an example in the following: A new technology emerges about which no opinion has yet been formed. A variety of factors influence the individual, who therefore changes opinions, updates his/her beliefs, eventually becomes akin to the technology and decides to adopt it. Once adopted, the technology can be used. The mode of use itself then determines the energy demand or supply, depending on the technology under consideration.

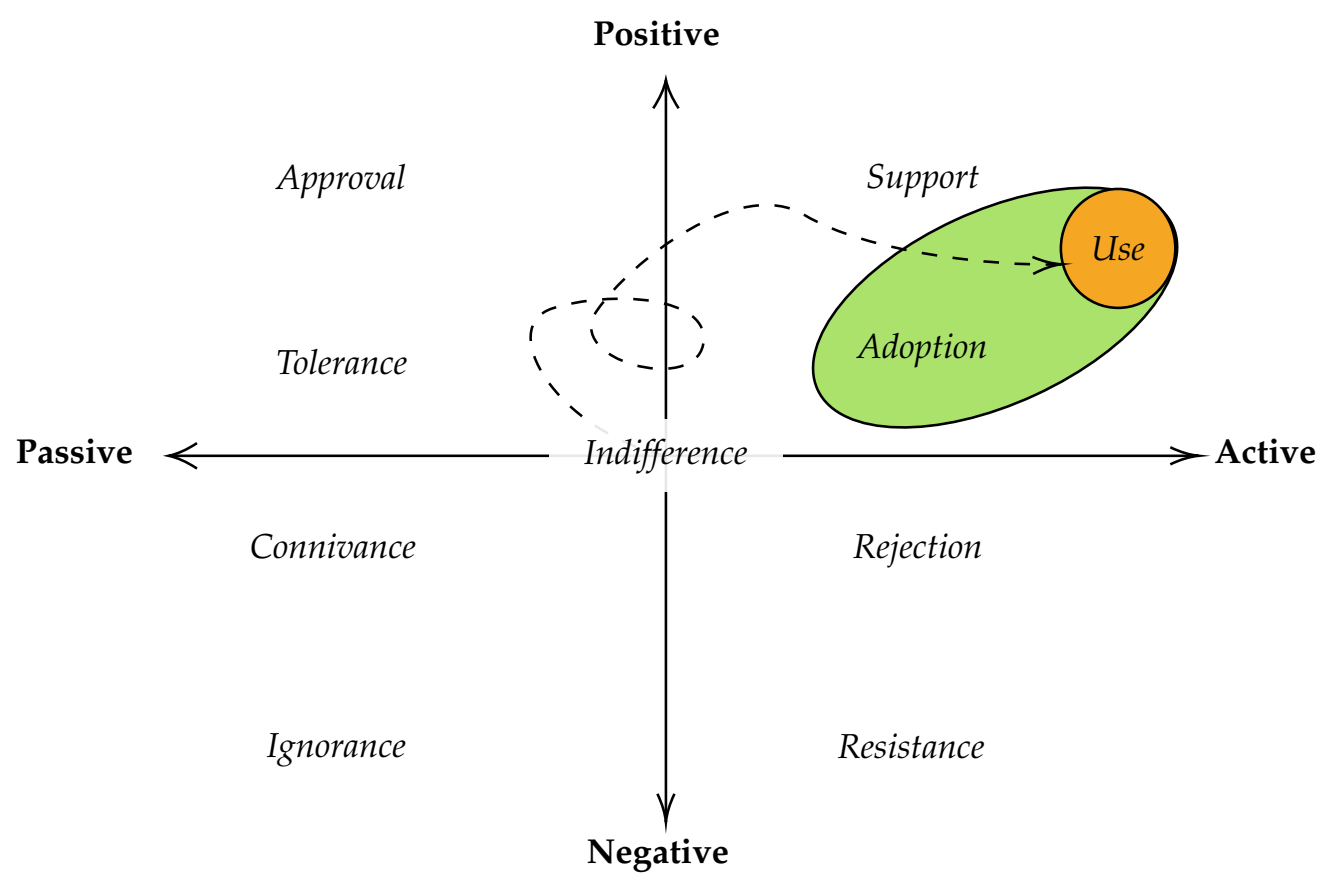

Figure 2. Acceptance model, based on [24]. 
This is of course only one scenario. The individual might as well develop a strong negative valuation of this technology. However, the purpose of the described scenario is to display that adoption and use of a technology lies within the field of acceptance. It should further be noted, that the word acceptance itself marks only one end of the spectrum. On the other end of the spectrum lies resistance against or the opposition of a technology, which is studied by Kleijnen et al. [25] who propose a framework for analysing consumer resistance.

\subsubsection{Adoption}

The literature on the topic of technology adoption provides few definitions or categorisations. The foundation for a large part of the literature is "Diffusion of Innovations" by Rogers [26] describing adoption as "a decision to use and implement a new idea". This is very similar to our understanding, where we consider the decision to adopt and the behaviour associated with the use as two distinct categories, in line with the approach adopted in bottom-up modelling of energy demand [27]. The act of adopting a technology or service involves a decision-making process and is thus far from trivial but not the primary focus of this work.

Particularly on the demand side, understanding the adoption behaviour of climateneutral mobility or heating technologies is important for the energy system development since a large energy demand arising from these sectors is currently supplied by fossil fuels in the form of gas or oil-derivatives. To meet the climate targets, these energy carriers soon need to be replaced using climate-neutral alternatives such as renewable electricity. This may require increased expansion of electrical energy generation and transmission capacity.

\subsubsection{Use}

Ultimately, supply and demand from any energy technology are determined by their use, since even adopted technologies may remain unattended by their owners. Given the lack of a definition in the literature, we generally define "use" of a technology or service as the intensity and time of its use. Thus, use of a technology or service adheres to human behaviour that translates into an energy demand or supply. For the sectors of mobility and residential heating, this translates into the kilometres travelled or average vehicle speed and the average room temperature, respectively. These measures serve only as examples, but are representative for behavioural patterns that can not only differ substantially between individuals but can also be influenced and changed.

\subsection{Research Hypothesis and Structure of the Paper}

In this work, we hypothesise that the fields of energy system modelling and behavioural research with a focus on decision-making in relation to acceptance, adoption and use of energy technologies have coexisted independently for too long and should be combined urgently (see Figure 3). The integration of behavioural aspects might greatly improve the capabilities of ESMs to produce more reliable results to inform policymakers and to develop societally feasible pathways for transforming the energy system.

The remainder of this paper is organised as follows. In Section 2, we provide an overview of state-of-the-art research in each of the yet largely separate fields of energy system modelling and behavioural research focussing on the acceptance, adoption and use of energy technologies or services. In Section 3, we present the research approach adopted outlining how the literature was reviewed and which fields were investigated. Subsequently, in Section 4, we describe the emerging approaches in the field of combining behavioural research and energy system modelling that have been identified by means of the structured literature review. In Section 5, we discuss our findings as well as research priorities for the future. Section 6 concludes the paper. 


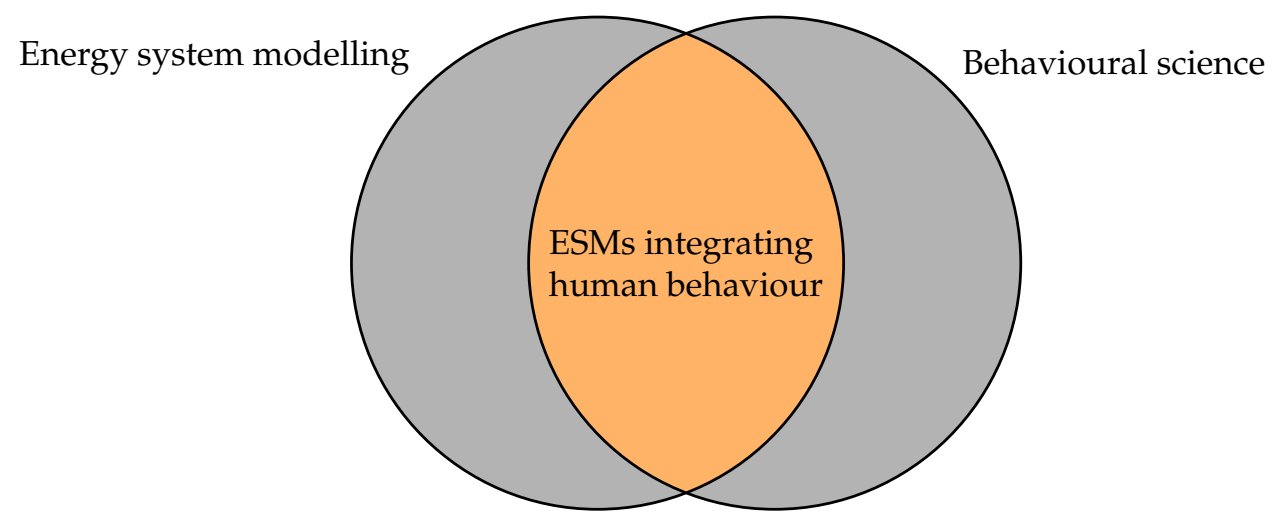

Figure 3. Hypothesised intersection of the disciplines of energy system modelling and behavioural sciences.

\section{State-of-the-Art Methods and Tools}

This chapter aims at describing prevailing methods to model energy systems and human behaviour in the energy sector. Note that these are research fields with a large and fast growing literature. Therefore, the selection of research findings cannot be comprehensive and is, to some extent, subjective of course.

\subsection{Energy System Models}

According to Möst et al. [28], energy system models can be categorised into top-down models, depicting energy systems and their interaction with the wider economy on the basis of macro-economic indicators and bottom-up models, which can be further divided into optimisation and simulation models. In line with our primary research focus, we aim to give a brief overview of these two distinct methodologies. For an in depth comparison between simulation and optimisation models, see [29]. While these two groups of models are the most prominent, many other models have emerged recently. Pfenninger et al. [4] review models relevant to energy policy on a national and international level and distinguish between optimisation, simulation, market and mixed-method models. Four major challenges are derived for models that are capable of depicting a twenty-first century energy system, namely the spatio-temporal resolution, dealing with uncertainty, growing complexity of the systems and the integration of human behaviour. For detailed reviews of energy system models, see [11,30,31]. Ringkjøb et al. [32] and Helistö et al. [33] focus on methods accounting for large shares of vRES, whereas Senkpiel et al. [34] provide a rather detailed classification of energy system models in their review. Furthermore, open source models are collected and listed on the openmod website [35].

\subsubsection{Optimisation Models}

Optimisation models use inputs comprised of techno-economic parameters about energy related technologies, and compute optimal investments and scheduling thereof based on a target function, that usually minimises cost. This is most often accomplished using linear (LP) or mixed-integer linear programming (MILP). Early proponents of energy system optimisation models are MESSAGE (Model for Energy Supply System Alternatives and their General Environmental Impact) [36] and the MARKAL (Market Allocation) model [37], that evolved into the TIMES (The Integrated MARKAL EFOM System) model [38] by combination with the EFOM (Enery Flow Optimisation Model). Variants of these models have emerged in recent decades, each with a focus on either a specific sector or country.

This category has seen the largest share in newly available models, in the 2000s and 2010s where ease of use and increasing flexibility are of growing interest [39]. Examples of recent developments are PyPSA-Eur, that covers the European transmission grid, but also allows for country specific analysis, by accessing openly available data [40] and Backbone, which allows for modelling of generic systems through flexible depiction of energy carriers, grids and spatio-temporal resolution [41]. Due to the data-driven optima in these models, 
further developments focus on addressing the underlying uncertainty regarding assumptions about future technology developments particularly for multi-energy systems [42,43] and distributed systems [44-46].

\subsubsection{Simulation Models}

In contrast, simulation models do not aim for a cost-minimal system, but rather illustrate energy supply and demand in a descriptive manner allowing for the depiction of stochastic, random or strategic behaviour of stakeholders [28,47]. They can furthermore take micro-economic decision-making and drivers of technology diffusion into account [34] and are more focused on exploring alternatives [29]. In this domain, well known models are the National Energy Modeling System (NEMS) [48] developed originally for the American energy system, and the Price-Induced Market Equilibrium System (PRIMES) [49] for the European energy system. Within this category, several subcategories exists. For instance, system dynamic models (SDM) and agent-based models (ABM). In their review, Bolwig et al. [50] present a system dynamics model, which is capable of capturing feedback loops, learning processes, policy and governance, behavioural changes, the inter-linkages between the energy sector and other economic sectors, and infrastructure development and the co-evolution of these factors over sufficiently long time periods. Furthermore, they state that combining SDM with technologically detailed optimisation models would be a step towards achieving more realistic modelling of sustainable energy transitions.

Agent-based models (ABM) are a specific case of simulation models, where actors participating in the energy system are explicitly modelled as agents allowing for distinct strategies and behaviour [32]. These allow not only for the simulation of technologies, but also for behaviour and activity modelling and consequently yield resource demands of every agent with high resolution [11].

\subsection{Behavioural Studies}

Researchers have studied consumer behaviour and environmental attitudes and their influencing factors for a long time. Conceptually, Black et al. [51] for instance distinguish between contextual (demographic, economic, structural) and personal (attitudes, beliefs, norms) factors. Guagnano et al. [52] differentiate between external and internal/attitudinal factors. These two categorisations have in common that they seek to establish causal models that can explain environmental behaviour. They are both based on Fishbein's attitudebehaviour model [53,54], extended by Ajzen in their theory of planned behaviour [55]. The theories by Fishbein and Ajzen posit that the influence of external (socio-demographic) factors on people's energy-related behaviour and attitudes is typically rather indirect than direct. Later, Venkatesh et al. [56] combined these theories along with the technology acceptance model (TAM) by Davis et al. [57] and the innovation diffusion theory by Rogers [26] and further models into the so-called "unified theory of acceptance and use of technology" (UTAUT). In its initial form, UTAUT hypothesises that four key elements determine whether a user adopts a new technology: performance expectancy, effort expectancy, social influence, and facilitating conditions.

As described in Section 1.1, we distinguish between behavioural aspects related to acceptance, adoption and use of energy technologies and services, acknowledging that these aspects are not independent of each other. In the following subsections, we provide a summary of theoretical as well as empirical research results focussing on drivers and barriers of acceptance, adoption and use.

\subsubsection{Acceptance}

In terms of the public acceptance of energy technologies, Devine-Wright [58] distinguishes between socio-demographic, contextual and psychological factors. In their categorisation, contextual relates to aspects of technology type/scale, (institutional) structures, spatial context and (perceived) impact, whereas psychological refers to people's awareness and 
understanding, political and environmental attitudes and beliefs as well as aspects of place attachment and trust.

In terms of the socio-demographic factors, many studies find age to have a significant effect on the acceptance of renewable energy technologies or grid expansion projects, though there is mixed evidence on the exact impact(while Cohen et al. [59], find acceptance of transmission line expansion to decrease with age, Vorkinn and Riese [60] find acceptance of a hydro power projects to be lower among younger people). Only few studies find gender to be a significant predictor variable and, as with age, there is mixed evidence concerning the effect (while Dietz et al. [61] find women to be more likely to be pro-environmental, Vorkinn and Riese [60] find lower hydro power acceptance among females). Concerning education, Bidwell [62] finds this to be the only socio-demographic characteristic with a direct significant effect on people's attitudes towards wind turbines (with slightly increasing wind caution for people with higher education levels). In terms of household income, Vorkinn and Riese [60] find that households with higher incomes are more likely to reject hydro power projects. In addition, Devine-Wright and Batel [63] find that the socio-economic status has a significant effect on people's attitudes towards pylon design. Moreover, existing studies find the length of residence (describing how long people have lived in their current place of residence), and the area of residence (urban or rural) to be variables with a significant effect on landscape-related and place-related preferences and perceptions [63-65]. In summary, the diverse results presented here in terms of the effects of the external/socio-demographic factors on the acceptance of energy technologies across a number of different studies show that the effects in detail largely depend on the specific context and the considered technologies [66].

In terms of the contextual factors, many studies identify the perceived visual impact on the landscape as one of the most relevant predictor variables explaining people's opinions particularly in the case of wind turbines and power lines [62,63,67-70]. The perceived impact of noise on people's attitudes is also mentioned regularly [67,68,71]. Moreover, researchers have identified the perceived local impacts of energy technologies on the environment, economy and employment as relevant factors [62,68,71,72]. Poortinga et al. [73] and Soini et al. [74] discuss the role of perceived health and safety effects in driving public attitudes towards power generation and transmission technologies, whereas the role of odour is highlighted specifically for biomass [75]. Concerning distance (e.g., the distance between people's homes and renewable energy developments), existing studies find mixed evidence in terms of its exact effect: While studies in [76] do not find a significant relationship between proximity and acceptance, others find evidence in support of the so-called proximity hypothesis [77-80].However, they explicitly state that distance is not a primary determinant of acceptance or opposition but rather an aggregated driver that mediates many of the other impacts in the surroundings of a certain energy technology development (e.g., visual or noise-related impacts), an understanding that is also supported by Rand and Hoen [81]. Other studies, e.g., [22,82,83], also find distance as one of the most important factors influencing public acceptance of solar PV or wind farms. Furthermore, existing research has shown that the scale of renewable energy projects has an impact on their acceptance or rejection [84-87]. In particular, Molnarova et al. [88] find the number of wind turbines to be important. An inverse relationship between the scale of wind projects and acceptance at the community level has been identified in the UK [89], the Netherlands [90] and Ireland [68]. More specifically, Tsoutsos et al. [91] find a correlation between wind farm scale and perceived negative impacts (such as shadow flicker) for a case study in Greece. Moreover, for the same capacity of a wind energy project, people are found to favour a cluster of larger turbines over greater numbers of smaller turbines in their vicinity.

In terms of the role of psychological factors, theoretical as well as empirical studies have found a link between environmental concern in principle on the one hand and acceptance of renewable energy technologies as well as behavioural intentions more generally on the other hand $[62,73,92,93]$. Existing research has also found evidence that political preferences are correlated with people's attitudes towards energy infrastructure $[61,63,93,94]$. In addition, 
Dietz et al. [61] find that people's judgment is significantly affected by the tradeoff they make between economic and environmental objectives. Many other factors have also been analysed concerning their effects on the acceptance of energy technologies. Most importantly, many studies find place attachment to be more significant in various settings than any standard socio-demographic variable [60,62,65]. Moreover, Emmerich et al. [19], Upham and Shackley [75], Zoellner et al. [95], Aitken [96], Terwel et al. [97], Huijts et al. [98], Ciupuliga and Cuppen [99], Aaen et al. [100], Butkowski et al. [101], Caporale et al. [102] and others analyse how acceptance is affected by trust and perceived fairness. Finally, the role of experience, awareness and information has also been studied (e.g., [63,103]) and there is a large and growing literature on the relevance of institutional aspects, ownership structures and community involvement mechanisms (e.g., $[78,85,104-106])$.

\subsubsection{Adoption}

Technology adoption is closely related to the terms technology diffusion [26] as well as market penetration and market acceptance [20]. In this paper, we do not differentiate between these terms. There is a wealth of research investigating drivers of consumer decisions towards the adoption of climate-neutral technologies in the mobility (e.g., electric vehicles), heating (e.g., heat pumps) or electricity (e.g., rooftop PV modules) sectors (e.g., [2,107,108]).

Concerning the adoption of electric vehicles (EVs), Sovacool [21] and Adnan et al. [109] synthesise a framework aimed at a better understanding of what determines adoption decisions. Others focus primarily on the intention of adoption with an identity based model [110], the unified theory of acceptance and use of technology (UTAUT) [111] or an extended theory of planned behaviour [112]. McCoy and Lyons [113] use an agentbased microsimulation model to assess the diffusion EVs among Irish households and find that mild peer effects may affect the diffusion and can result in clusters of adopters forming in certain areas. Barbarossa et al. [110] find that green self-identity plays a role in driving the adoption of EVs. Ensslen et al. [114] combine a top-down macro-econometric Bass model [115] and a bottom-up micro-econometric binary logistic model to compare the adoption of plug-in EVs in Germany and France. They find that the adoption rates are slightly higher in France compared to Germany. Kühl et al. [116] focus on consumer preferences related to the market uptake of electric vehicles. While the analysis of pricerelated needs and needs related to car characteristics dominates the scientific literature, charging-related needs turn out as dominant in a Twitter data set.

Concerning the understanding of household-level energy efficiency and heating system investment decisions, e.g., Aravena et al. [117] investigate drivers of household-level energy efficiency investments in general, whereas Curtis et al. [118] specifically focus on understanding the determinants of household heating system upgrades. Both studies highlight the importance of information and knowledge of householders for the outcome of their decision-making processes. Furthermore, Heiskanen and Matschoss [119] review the literature to explain differences of diffusion patterns for heat supply technologies across European countries. Robust similarities for the drivers and barriers of adoption patterns such as access to capital, home ownership, education and specialisation and insights to EU-differences from the household over the local environment to the national context have been derived.

Concerning the adoption of low-carbon electricity generation technologies, numerous studies investigate the decision-making behaviour behind the corresponding investment decisions at the household level (for instance, see the review for solar PV adoption by Scheller et al. [120] in this same special issue). Willis et al. [121] analyse the likelihood of UK households to adopt micro-generation technologies (including solar PV) and find that older person households are less inclined to adopt such technologies. Similarly, Balcombe et al. [122] find that younger age groups are more inclined to consider the investment in micro-generation but less frequently reach the point of actual installation, which suggests that other barriers prevent these households from installing. Yamamoto [123] confirms the hypothesis that there is a positive relationship between the willingness to pay 
for a solar PV system and opinion leadership on PV-system adoption. Ropuszyńska-Surma and Weglarz [124] find that the area of residence, building type, age and income are significant determinants of the households' willingness to install renewables in Poland. They also mention that the adoption of low-carbon electricity generation technologies is closely linked to the discussion on so-called prosumers (consumers that also become producers) [125], which in turn is closely linked to aspects of energy autonomy or autarky [126] as well as self-sufficiency and self-consumption [127-129].

Furthermore, recent research findings show links between acceptance and adoption. More specifically, Schweizer and Bovet [130], Liebe et al. [131], Renn et al. [132] find that adoption behaviour related to active engagement in energy autonomy initiatives and technologies increases (community) acceptance of energy technology developments. Similarly, studies in the UK have demonstrated high levels of acceptance to local power production from solar PV and wind. Other studies also show that locally embedded renewable development and use enhanced local public acceptance [133,134]. Similarly, Schumacher et al. [135] provide an empirical comparison of public acceptance of renewable energy developments and attitudes towards energy autonomy in Germany, France and Switzerland. According too their study, the majority of participants across all three countries generally have a strongly positive attitude towards energy autonomy. In their study, they also compare the participants' experience with renewable energy in forming opinions about energy autonomy with their "disposition to act towards local renewable energy", and find that the participants' positive experience and familiarity with renewable energy are important aspects. Across all three countries, participants with renewable energy projects in their surrounding indicate more positive attitudes towards local energy autonomy than those without. Emphasising the fact that regions can increase their energy autonomy via locally-available (renewable) energy sources has gained growing attention as a potential mechanism for increasing public acceptance of energy technologies (e.g., [136,137]). Complementing this finding, the so-called energy democracy continues to emerge as a societal movement in energy demand and supply [138,139].

\subsubsection{Use}

Beyond the adoption of energy technologies, the way they are used (e.g., times, frequency) has an important impact on the medium-term and long-term energy demand and system development (e.g., in terms of costs, emissions or reliability). It is therefore highly relevant to understand the behavioural aspects and determinants that drive the (times of) use of technologies, such as room heating [140], electric vehicles [17], dishwashers and washing machines [141] or refrigerators [142]. In this context, Brazil et al. [143] study the relevance of socio-economic characteristics in predicting peak period appliance use. This topic is closely related to socio-economic research studying consumer preferences and behaviour in relation to demand response (see [144], for a review) and the introduction of new retail tariffs, including elements such as dynamic pricing $[145,146]$ or curtailable/externally-controllable load [147-149] as well as the elasticity of energy demand (e.g., [150,151]). Furthermore, the theoretical background of so-called inverse demand curves is well-established (e.g., [152]). Yet, there is a lack of understanding of the (heterogeneity of the) shapes of different consumers' demand curves and economic considerations of demand side responsiveness tend to focus on extreme events using the value of lost load (VOLL) [153,154] or analyse the costs of supply interruptions [155] rather than examining the entirety of the demand curve [156].

\subsection{Summary of the State of the Art}

As highlighted in Section 2.1, numerous energy system models have been developed to date aiming to provide structured support for decision-making in the context of the transformation of the energy system. However, these models typically have a strong techno-economic focus, which is not sufficient to support decision-making processes in practice. In particular, the understanding and consideration of behavioural and societal 
drivers and barriers is key to enable a societally feasible transformation of the energy system towards climate-neutrality. As outlined in Section 2.2, manifold studies have provided insights into drivers and barriers of the acceptance, adoption and use of energy technologies and services. Yet, the knowledge, insights and methods of these largely distinct research areas are not integrated. We therefore second the need for integrating human behaviour and social risks and opportunities into energy system models as outlined by Pfenninger et al. [4], which is a research area that is still largely under-researched.

More precisely, there is a gap in the literature in terms of translating the behavioural research outputs into explicit parameters that can be used in ESMs to assess the energy system impacts of the findings from behavioural research. For the case of contextual factors that influence the acceptance of energy projects (e.g., the setback distance or scale of renewable energy technology developments) first approaches have been proposed $[157,158]$. However, for the consideration of psychological factors in energy system modelling, for instance, the authors are not aware of any existing research. Likewise, policies aimed at strengthening the exchange of information and knowledge between the relevant energy system actors, including individuals, firms or organisations cannot be captured by existing ESMs [34]. On the other hand, existing behavioural research does not take into account the consequence assessment provided by ESMs. Preferences are typically elicited from individuals in a mono-directional way without considering the preferences' system effects and how these in turn could change the preferences in the first place. In Section 3, we therefore present a structured literature research approach that is aimed at identifying emerging research that combines behavioural research findings and energy system modelling as illustrated in Figure 3, the results of which are subsequently presented in Section 4.

\section{Research Approach}

In order to identify the potential overlap of the fields outlined in the previous chapter, a structured literature review was performed by searching on scopus. The resulting papers of the search, hereafter called corpus, were filtered and analysed by interpreting the works therein as a citation graph. In this graph, papers represent vertices (nodes) and citations are edges. In order to reduce the size of the corpus to a manageable amount, a series of filters was applied. These operations are summarised in Table 1 and will be described in the following. The underlined results have been kept for further research.

Table 1. Search query and further operations performed on the corpus. The operators "?" and "*" allow for word completion with one or any numer of characters respectively.

\begin{tabular}{ccc}
\hline Initial \# of Publications & Query/Operation & Resulting \# of Publications \\
\hline $76.8 \mathrm{M}^{1}$ & $\begin{array}{c}\text { (behavio* OR human* OR decision OR accept* OR }^{*} \text { adopt* OR use* AND “energy system?" AND techno* }^{*} \\
(\text { model OR optimi* OR simula*) }\end{array}$ & 4761 \\
4761 & top decile based on citations & 1890 \\
1890 & high paper betweenness & 73 \\
1890 & high author betweenness & 42 \\
\hline
\end{tabular}

${ }^{1}$ As stated by the Scopus Content Coverage Guide (available at: https:/ / www.elsevier.com/solutions/scopus/how-scopus-works/content; accessed on 5 June 2021).

The first two rows of the table depict queries, where the words had to appear in the title, abstract or keywords. The question mark and asterisk allow for continuation of the words with one or any number of characters, respectively. This limited the corpus to 1890 documents. The result of the filtering can be seen in Figure 4. 


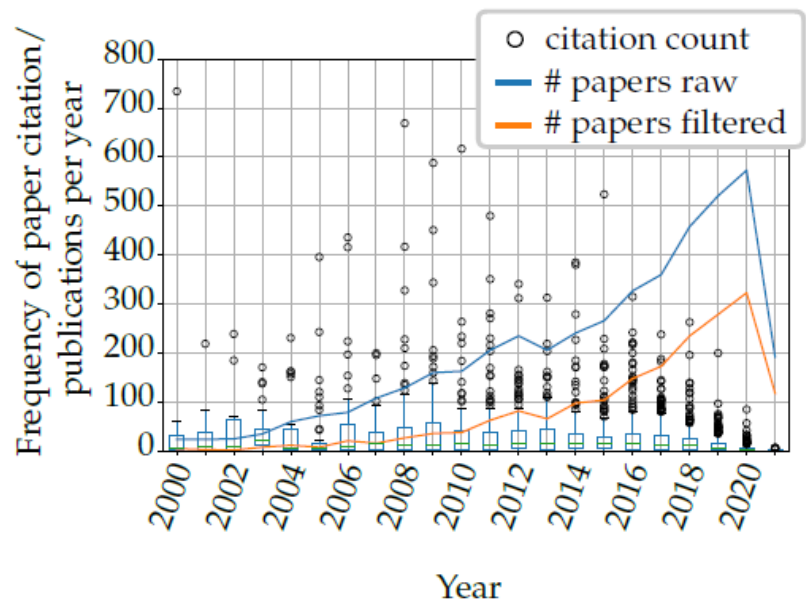

(a) Publication and citation frequency. Lines represent yearly publications, boxplots show the citation distribution for papers published in a given year.

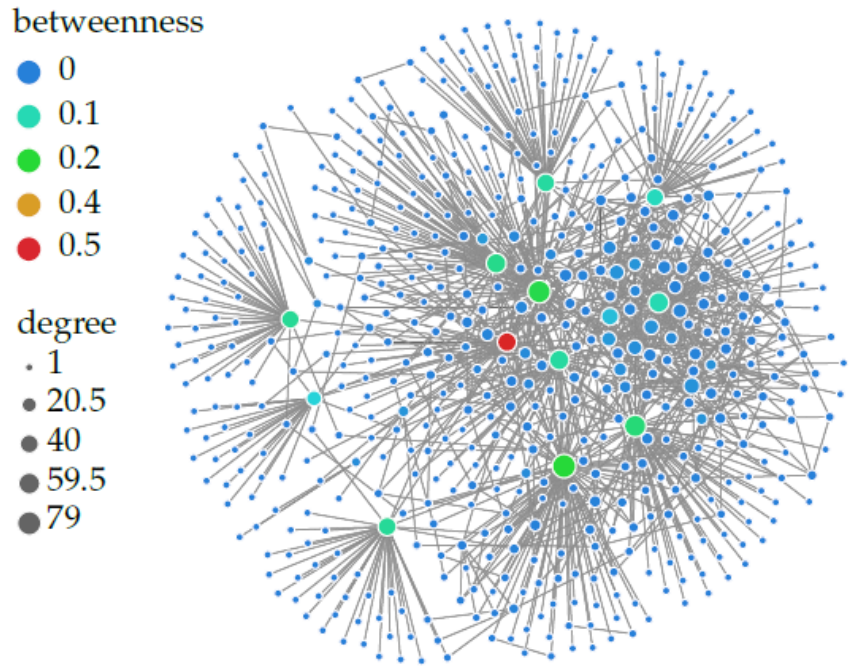

(b) Exemplary graph showing vertices scaled by degree and coloured by betweenness. Note: vertices with a high degree do not necessarily have a higher betweenness.

Figure 4. Methods used for filtering. (a) shows the approach of citation based filtering and (b) displays the concept of betweenness as an indicator for papers that potentially bridge gaps between disciplines.

In order to further reduce the amount of papers, the $10 \%$ most cited papers of each year were selected. Note that using only the citation count would discount more recent papers as displayed in Figure 4a. This limited the size of the corpus to 183 documents. Yet, emerging approaches and works that are ahead of their time, will likely be excluded by this procedure since they are still "emerging" and thus low in citation count.

Therefore, we also consider the betweenness of papers to identify additional potentially relevant papers. Betweenness is a measure of centrality in a graph and can be calculated using the shortest path between vertices. More precisely, all shortest paths between all possible pairs of vertices are calculated. The fraction of shortest paths that pass through a vertex defines its betweenness [159]. Vertices with only a few edges can consequently have high betweenness if they connect otherwise almost separate clusters. In the context of our corpus, one could argue that papers with high betweenness might connect disciplines, and can hereby be identified without relying solely on citation count. Hence, a citation graph, was built based on papers within our corpus, and their references obtained through the Scopus API with the pybliometrics package [160]. Then, the betweenness was calculated [161] and a total of 73 papers with high betweenness are added to the selection. A subset of the citation graph can be seen in Figure $4 \mathrm{~b}$ (plotted with [162]). Note the difference between the degree (total number of edges) and betweenness. The same procedure was pursued for authors, where collaborations of authors are graphed selecting papers of authors with a high betweenness adding 42 papers to the selection.

Finally, the selected 298 papers were manually screened for relevance. If a paper included any form of behaviour integration into an ESM, it was marked as relevant, which resulted in merely 43 relevant papers. Ten of these papers were review papers, that provided insights as to why behaviour is important but did not come up with solutions to this issue. This large reduction, can in part be explained by the broad notion of the term "behaviour" frequently used to describe, e.g., "system behaviour" (in a technical sense), which is not the focus of this study.

\section{Emerging Approaches and Challenges}

The emerging approaches as identified by the procedure described in Section 3 were categorised with respect to behavioural aspects and the respective technology as in Figure 1. While approaches of integration for each behavioural aspect exist, the absolute number 
thereof is very small. As expected, no works dealt with the active use of large vRES or transmission. Use was more popular among the categories of micro-generation, EVs and Services. However, this is rooted in the fact that many models for demand or load forecasting exist, that fall into this category. Furthermore, it was found that a few approaches on the topic of integrating acceptance of large vRES into ESM are emerging. These along with the co-occurrence of the other categories are visualised in Figures 5 and 6 and will be described in the following.

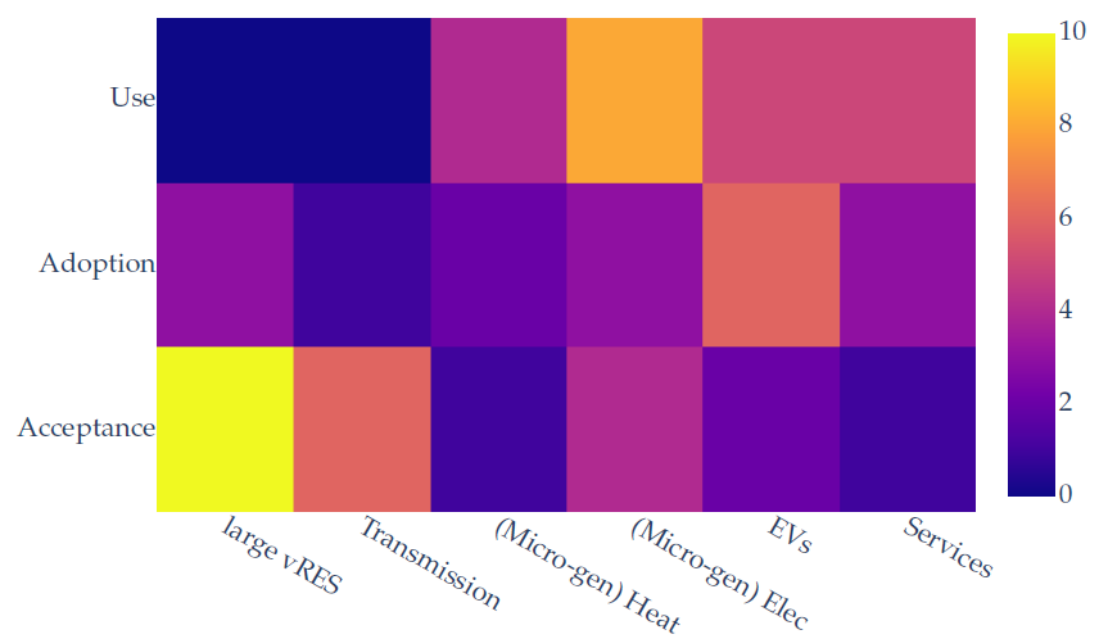

Figure 5. Findings in the intersection of behavioural aspects and technologies or services considered.
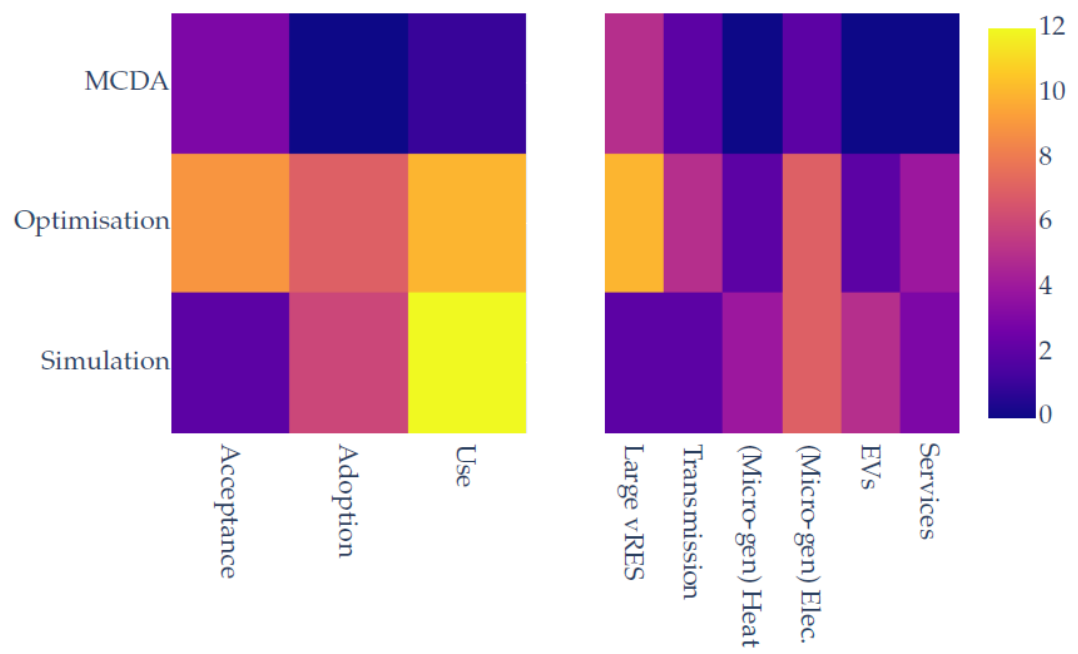

Figure 6. Findings in the intersection of behavioural aspects and technologies or services considered.

\subsection{Integration of Behavioural Aspects in Energy System Models}

Although in 2009, reviews fell short of mentioning humans or their behaviour as relevant factors for optimisation [163], the notion of their importance emerged shortly thereafter by Connolly et al. [31] who describe models that represent behavioural patterns of "agents" in the electricity system. However, the integration of these patterns into the domain of energy system modelling has since only been regarded as a difficult challenge of model integration [11], although significant potential is expected in understanding the challenges at the interface of technology and behaviour [164]. Since then, some approaches have been developed to account for different aspects of human behaviour.

\subsubsection{Considering Acceptance}

Incorporating acceptance into an ESM and accounting adequately for its complexity is a challenging task. Therefore, some implementations fall back to scenarios entirely 
excluding a technology for which acceptance might be low, i.e., for CCS in investigations on the diffusion of hydrogen technologies [165].

However, more sophisticated attempts to integrate acceptance into optimisation models have been presented, too. For instance, Bolwig et al. [166] noted well-documented effects of low acceptance towards wind parks, stated a lack in the assessment of societal and developer costs and developed an approach of integrating low acceptance in an optimisation model in the form of added system costs caused by suboptimal placement of wind turbines and transmission lines. These additional costs have been explicitly included as model inputs. Their result of up to $12 \%$ increased consumer costs for a low acceptance scenario indicates that inclusion of social factors can significantly affect results. Similarly, Wingenbach [167] integrated acceptance as a degree of land-utilisation into an ESM leading to a more evenly distributed installation of wind parks. Results indicate only a slight increase in cost, yet supposedly higher societal acceptance and therefore higher chances of a successful energy transition. Fitiwi et al. [157] argue that increased distance, reduced turbine size and increased regional self-sufficiency each have a positive effect on the public acceptance, while they constrain the available potential for onshore wind capacity development. They find that in the constrained case, the system costs are only marginally higher than in the base case, while they observe substantial differences in the final generation portfolios. Koecklin et al. [158] come to broadly similar conclusions, where they derive the modelling constraint representing public acceptance from results of a nationally-representative survey.

A novel concept is presented by McKenna et al. [168], who involved a community in an iterative ESM and decision-making task. Preliminary results of an ESM were shown to a panel of stakeholders, conveying preferences and constraints to build alternatives of possible future energy systems. Alternatives were then ranked with an MCDA tool to select the system that performed best not only in terms of cost, but in terms of an overall performance score.

Interestingly, no work has been found belonging to the family of simulation models, that accounts solely or in greater detail for acceptance. Albeit in small numbers, the trend of analysing the acceptance of wind appears to slowly diffuse into the domain of modelling.

\subsubsection{Describing Adoption}

The adoption behaviour is slightly more often integrated in optimisation models than in simulation models (see Figure 6). Despite the lack of a theoretical foundation, a common way for considering adoption behaviour in energy system models is the use of varying diffusion or hurdle rates [5]. For instance, Ghatikar et al. [169] account for adoption of technologies by using DER-CAM (distributed energy resources customer adoption model) and for use of the technology or energy by integrating DR. Research from the field of energy finance also recommends that energy system models with capacity extension should consider project-specific rather than uniform costs of capital (e.g., [170]). Note, however, as mentioned above that there is no theoretical foundation for such an approach. In fact, following such a procedure would to some extent violate one of the fundamental axioms on which ESMs are built, i.e., the availability of a perfect financial market with equal access of all market participants to uniform costs of capital). While not explicitly modelling adoption as a purchase decision, Hahnel et al. [171] determines individual trading behaviours via survey for a potential peer-to-peer electricity market as probabilities to trade as a function of current battery state-of-charge (SOC), and analyse the effects of electricity price change in price-focused, autarky-focused and heuristic prosumer groups. This contribution addresses the lack of behaviour in the domain of demand response, where users decisions or their willingness to participate is often marginalised to binary variables. Pye and Daly [172] integrate the shift in transport behaviour from one form of transportation to another (modal shift) in an ESM. While an increase in cycling and public transport shares are observed, thereby reduced emissions allow for an increased use of higher emission vehicles. Avoiding such rebounds will be an important challenge for the 
future. They also point out that up to $15 \%$ of urban travel demand could be shifted from car to other modes, reducing mitigation costs by $20 \%$. A similar approach has been taken by Daly et al. [173], who incorporate modal shift with the additional parameter of travel time investment into the TIMES model allowing decision-makers to analyse the impacts of investments into the public transportation sector.

Simulation models dealing with adoption behaviour have been developed with a high level of detail. For example, Steinbach [174] aims at identifying measures for the expansion and increased diffusion for energy-efficiency upgrades in the German residential sector. To do so, the existing built environment, individual investment options and barriers as well as drivers of heat-related technology adoption (particularly energy-efficiency upgrades) were analysed and incorporated in an agent-based model. Then, the effects of policy measures were analysed, concluding that increased government regulation yields the sharpest decrease in residential heat demand. Economic incentives are seen as an inadequate alternative due to high investments, that yield returns very late. Ideally these policies are imposed cooperatively. Others used an agent based model to study dynamics of consumer opinions on electricity tariffs. Offering an explanation to the discrepancy between consumer opinions, determined by market surveys, and actual participation or adoption (e.g., [175]).

These approaches provide a solid foundation for a thorough assessment. When combined, policies might be evaluated with regards to the effects on travel mode, willingness to participate in DR measures and energy trading behaviour.

\subsubsection{Modelling Technology Use}

The depiction of use in ESMs varies strongly. Sometimes demand across all sectors is simply assumed to decrease over time, as a result of growing efforts in education resulting in higher awareness [176] or increasing energy efficiency more generally. Others assume the amount of consumers willing to participate in DR is solely determined through a function of expected monetary compensation [177] or as a response to energy price changes in MARKAL [178]. Similarly, Rastegar et al. [179] treat the individuals' behaviour as rather static (i.e., always wanting a fully charged car in the morning). Atia and Yamada [180] consider the habitual nature of behaviour as non-controllable appliances (cooking, hair drying), whereas Anvari-Moghaddam et al. [181] depict behaviour of occupants in an ABM through maintaining certain comfort levels defined by room temperature intervals. Accounting for the stochasticity of activities, Good et al. [182] provide a high resolution demand profile model, including effects of adoption of heating technologies (e.g., heatpumps) by mapping activities to appliances. Another activity-based approach is presented by Bustos-Turu et al. [183] using an agent-based model. Likewise, demand flexibility through DR has been implemented in game theoretical models [184,185].

While these models deliver energy demand and appear to do so with increasing accuracy, the underlying behavioural patterns are poorly accounted for. A promising approach in this regard is presented by Lee and Malkawi [186] with an ABM where actors can adjust clothing levels to increase comfort level. While this is not an ESM, it demonstrates clearly how behavioural patterns or habits affect energy demand.

\subsubsection{Consideration of Multiple Behavioural Aspects}

While some approaches appear tailored towards a specific behavioural aspect, other approaches exist that either adopt a rather holistic perspective on behaviour or did not differentiate between behavioural patterns. For instance, with MEDEAS, Capellán-Pérez et al. [187] formulate an integrated assessment model, based on system dynamics, that focuses on longterm outcomes of the human-nature interface. They include household energy demand calculated with behavioural equations, which adheres to variations for example by changes in the share of vehicles and their efficiencies. On the other hand, adoption (market penetration) of vRES is assumed statically high, during the modelling horizon. Furthermore, results are interpreted with respect to societal impacts, which is beyond what most current models 
do. However, it is noted, that interpreting the model outcomes in terms of societal damage functions remains a very challenging task.

Keirstead et al. [11] proposed land use-transport models (LUT) as they incorporate a form of behavioural realism through micro-simulations or activity based models with individuals as unit of analysis. Such simulations would need to account for the uncertainty caused by the nature of human behaviour which is stochastic by nature, varying not only between people but also in time [45].

Li and Strachan [188] developed the "Behaviour, Lifestyles and Uncertainty Energy model" (BLUE), which is a system dynamics model accounting for a variety of behavioural factors. Demand elasticities, market heterogeneity, intangible costs/benefits, hurdle, retrofitting or replacement rates as well as variations in these factors are considered. Their model is aimed at modelling the so-called socio-technical energy transition (STET) [189] and is used in [190] to derive the impact of leader-decisions, where the leader (in terms of who drives the energy transition) is either the society or the government.

In order to derive the effectiveness of energy conserving measures (ECM) Sun and Hong [191] provide three behaviour representations in terms of energy consciousness: austerity, normal and wasteful. They conclude, that ECMs in terms of technologies that require little interaction are only marginally affected by different behaviour, whereas occupant-dependent ECMs such as active ventilation are significantly affected by behaviour. Furthermore, a factor of two lies between energy demand of energy conscious and wasteful behaviour. Le Gallic et al. [192] adopt a perspective of lifestyles and develop a model simulating current and possible future lifestyles largely influenced by cohabitation preferences and travel behaviour, and demonstrate that a more "collective society" contrary to current trends of growing individualism would reduce energy demand across all sectors.

Mavromatidis et al. [44] perform Monte-Carlo simulations for an energy system model to account for a plethora of uncertainty factors among which coarsely defined human behaviour is located. They include demand side variations through probabilistic descriptions of occupants.

\subsection{Model Coupling}

Another promising strategy is to couple simulation and optimisation models, which might enable capturing the interlinked effects of the demand and supply side of energy systems that otherwise evolve individually [193]. For instance, simulated energy demand or penetration rates of various technologies can serve as boundaries for modelling technology diffusion with optimisation models [34]. This approach, has been adopted with varying degrees of complexity and sectors considered [194-196]. Behaviour in these models is frequently depicted as a scope of action for agents subject to stochastic deviations in time and probability of actual occurrence.

Furthermore, coupling of models across disciplines has also been conducted. In the European CHEETAH project, investigations on a micro, meso and macro level were carried out deriving implications for households, the energy system and the economy as a whole, respectively. Insights from a discrete-choice experiment [197] were integrated into a demand and an agent-based model. Hence, behaviour heterogeneity relating to adoption of retrofits among different demographic groups could be analysed [198]. It was concluded that energy literacy among the population (across different nations) should be increased to allow customers to make better informed decisions [199]. Similarly, Sopha et al. [200] combine an empirical survey which is founded on a literature review for decision-making variables with an agent-based model incorporating different decision strategies among agents to derive patterns of heating system diffusion in Norway and analyse impacts of policy.

While these approaches appear promising, using the output of one model as input to the next prohibits examination of feedback loops or rebound effects. Thus, evaluating policies and their possible effects on behavioural change with regard to energy remains challenging. 


\section{Discussion}

As mentioned in the previous section and shown in Figures 5 and 6, the number of articles concentrating on the consideration of behavioural aspects in energy system models is (a) comparatively small in total and (b) can be subdivided largely into three categories: First, approaches exist that consider acceptance of large-scale vRES or transmission lines mainly in optimisation models. Second, the consideration of aspects related to technology adoption so far have a strong focus on EVs using both optimisation and simulation models. Third, behavioural aspects related to energy use are considered in both optimisation and simulation models for electricity micro-generation, EVs or services.

In terms of gaps in the existing research landscape, understandably, there is little to no research on the public acceptance of EVs or services or the use of large-scale vRES or transmission lines. However, Figure 5 reveals that the topic of behavioural aspects related to the adoption of heating as well as electricity micro-generation technologies or services is yet under-researched. At the same time, an improved understanding of drivers or barriers particularly of heating technology adoption is vital given the high share of greenhouse gas emissions from the heating sector and given that millions of individual actors need to make their own decisions with lock-in period of often more than 20 years.

Looking at the articles that consider acceptance of large-scale vRES or transmission lines as parameters in energy system optimisation models, including some of our own research, it should be noted that they often operationalise acceptance in a very crude way, e.g., focussing on distance. Of course, this is still a new field of research and early approaches cannot be expected to be perfect but it will be important to develop more sophisticated approaches that acknowledge the complex nature of acceptance as part of future research. In particular, as outlined in Section 2.2, the consideration of contextual factors of energy technology projects is very important for the understanding of acceptance or opposition. Yet, most existing approaches do not run their own surveys to gather such context-specific information. The use of values from existing articles, however, cannot be context-specific and is therefore highly questionable.

In terms of articles that consider behavioural aspects related to the use of energy technologies or services, Section 4.1.3 provides an overview of recent advances in the field showing that much of this research is closely linked to aspects of demand response, which in turn is very closely related to energy demand elasticity. Unfortunately, however, the use of uniform elasticities is still very common. While Devine and Bertsch [201] construct demand functions that are specific to consumer groups, day times and demand levels to consider consumer heterogeneity, the approach is rather conceptual without any direct elicitation of information from consumers. More efforts are required to construct realistic demand functions in realistic energy systems. This shortcoming warrants new research integrating the consideration of technical characteristics of the energy demand processes on the demand side as well as the socio-economic preferences of different consumers.

An additional challenge is related to the fact that people's preferences and behaviour are both heterogeneous and uncertain, i.e., they differ across sectors, regions and cultures, and their future development is highly uncertain (see also [5]). While the utility functions used in Computable General Equilibrium (CGE) models (e.g., see [202,203]) typically allow for specifying heterogeneous preferences implicitly reflecting aspects of consumer behaviour [34], such deep uncertainty and heterogeneity of socio-economic dynamics are usually not accounted for explicitly in existing bottom-up energy system models [204]. This is an important area for future research.

Finally, note that existing research on integrating behavioural aspects of decisionmaking in energy systems as identified in Section 4 typically does not specify the level at which the decisions are made. In reality, however, there is a variety of actors (e.g., individuals, institutions, larger groups of the society or the society as a whole but also media, opinion leaders, lobby groups or political parties) who have different interests and pursue different objectives (e.g., see [34]). Future research activities on considering behavioural drivers and barriers in ESMs should therefore seek to differentiate more strongly 
between different types of decision makers and consider how they interact and influence the perception and likelihood of implementation of the decisions made.

Critically reflecting our research approach, we wish to acknowledge that the search query only entailed the positive keywords of the acceptance spectrum. Moreover, we have focussed on energy system models in our search. While energy system models assist in the generation of system knowledge and provide highly valuable insights on interactions in energy systems and markets for decision makers, they will only ever be a part of the entire "solution." In order to provide orientation and transformational knowledge to decision makers, interactive and iterative decision support tools are needed, which can be used in transdisciplinary research settings so as to co-design recommendations for energy system transformation pathways with actors from society outside the research ecosystem. In this context, multi-criteria decision analysis (MCDA) and decision conferencing $[205,206]$ can provide indispensable value to decision makers, where energy system models can be used for the consequence assessment and provide quantitative input data for the MCDA.

While our search has delivered a number of articles that consider behavioural aspects in MCDA approaches, Figure 6 suggests that this is yet a somewhat under-researched area. However, as mentioned before, note that the primary research focus was on energy system modelling, not on MCDA. A comprehensive review of transdisciplinary research formats, MCDA and ESMs would have gone beyond the scope of one single paper.

\section{Conclusions and Outlook}

Identifying and assessing societally feasible transformation pathways towards a sustainable energy system are some of the most pressing challenges of humanity. Since the energy system is not a purely technical system but also reflects political frameworks and socio-technical interactions, the transformation of the energy system must be considered as a complex socio-technical process requiring an overall systemic approach that simultaneously takes into account ethical, societal, political, economic, environmental and technical dimensions.

In other words, while technological development will certainly play an important role in decreasing costs and enhancing the efficiency, as well as environmental compatibility, of future energy systems, the most pressing challenges relate to the questions of how to arrive at a consensus that meets the climate-neutrality targets and is supported by the society as a whole and how to implement the required measures of the corresponding transition pathway successfully. Yet, research in this area is neither adequately developed nor adequately funded.

While energy system models have been developed and used for several decades to support decision makers in governments and companies in developing and assessing energy system design alternatives, these models focus on the techno-economic and environmental dimensions only and are therefore not sufficient to answer the above-mentioned "how questions." In this paper, we have therefore conducted a systematic review of energy system modelling and analysis approaches that are capable of considering behavioural and societal aspects of decision-making in the energy sector in different contexts.

We generally find that this is a field of research that deserves greater attention in the future. Existing research in this field mainly considers acceptance of large-scale vRES or transmission lines in energy system models or focuses on the consideration of behavioural aspects related to energy use in either energy system optimisation or simulation models for electricity micro-generation, EVs or electricity services.

As discussed in Section 5 in greater detail, developing more sophisticated ways for integrating behavioural aspects in energy system optimisation or simulation models is of utmost importance in order to allow for behavioural realism of the output from energy system models. Such developments are particularly relevant to identify requirements for and assess the impact of behavioural change in long-term projections, which is very challenging to achieve $[2,107]$ but at the same time essential to avoid delays in the energy transition, which would render the targets unachievable altogether [207]. Advanced 
research is therefore needed to improve ways for operationalising behavioural research findings in energy system models that take into account the complex processes behind acceptance, adoption and use of energy technologies and services. In order to promote methodological advancements in this important area of research, increased funding sources need to be provided.

Beyond improving energy system models as such to better account for behavioural realism, we see a strong need for and potential in combining energy system models with MCDA and decision conferencing to be used in transdisciplinary research settings, as briefly discussed in Section 5. In order to serve this purpose optimally, energy system models need to be improved mainly in two directions, which are at least partly in conflict with one another: First, energy system models need to allow for multi-dimensional impact assessments, e.g., through multi-objective optimisation, to provide information on the consequences of alternative transition pathways with respect to multiple impact dimensions that are considered relevant by the corresponding decision makers and stakeholder groups. Second, the models need to be able to provide such quantitative impact assessments in near real-time to provide input into the discussions in decision conference settings. Such information is also essential for the relevant decision makers and stakeholder groups to validate their original preferences in the light of the corresponding consequences. This will open up a new level of research on socio-economic preferences and will provide the possibility to consider the corresponding model output in the co-design of energy system transformation pathways.

Author Contributions: Conceptualization, V.B. and D.H.; methodology, D.H.; resources and data curation, D.H.; writing-original draft preparation, V.B. and D.H. writing-review and editing, V.B. and D.H.; visualization, D.H.; supervision, V.B.; Both authors have read and agreed to the published version of the manuscript.

Funding: This research received no external funding.

Institutional Review Board Statement: Not applicable.

Informed Consent Statement: Not applicable.

Data Availability Statement: Not applicable.

Conflicts of Interest: The authors declare no conflict of interest.

\section{References}

1. United Nations. Paris Agreement, Paris, 2015. Available online: https://unfccc.int/process-and-meetings/the-paris-agreement/ the-paris-agreement (accessed on 26 July 2021).

2. Jackson, T. Motivating Sustainable Consumption: A Review of Evidence on Consumer Behaviour and Behavioural Change; Sustainable Development Research Network: Guildford, UK, 2005.

3. de Coninck, H.; Revi, A.; Babiker, M.; Bertoldi, P.; Buckeridge, M.; Cartwright, A.; Dong, W.; Ford, J.; Fuss, S.; Hourcade, J.; et al. Strengthening and implementing the global response. Global Warming of $1.5^{\circ} \mathrm{C}$. An IPCC Special Report on the Impacts of Global Warming of $1.5^{\circ} \mathrm{C}$ above Pre-Industrial Levels and Related Global Greenhouse gas Emission Pathways, in the Context of Strengthening the Global Response to the Threat of Climate Change, Sustainable Development, and Efforts to Eradicate Poverty. 2018, 313-445. Available online: https:/ / www.ipcc.ch/sr15/ (accessed on 27 July 2021).

4. Pfenninger, S.; Hawkes, A.; Keirstead, J. Energy systems modeling for twenty-first century energy challenges. Renew. Sustain. Energy Rev. 2014, 33, 74-86. [CrossRef]

5. DeCarolis, J.; Daly, H.; Dodds, P.; Keppo, I.; Li, F.; McDowall, W.; Pye, S.; Strachan, N.; Trutnevyte, E.; Usher, W.; et al. Formalizing best practice for energy system optimization modelling. Appl. Energy 2017, 194, 184-198. [CrossRef]

6. Axsen, J.; Sovacool, B.K. The roles of users in electric, shared and automated mobility transitions. Transp. Res. Part D Transp. Environ. 2019, 71, 1-21. [CrossRef]

7. Wadud, Z.; MacKenzie, D.; Leiby, P. Help or hindrance? The travel, energy and carbon impacts of highly automated vehicles. Transp. Res. Part A Policy Pract. 2016, 86, 1-18. [CrossRef]

8. Sütterlin, B.; Brunner, T.A.; Siegrist, M. Who puts the most energy into energy conservation? A segmentation of energy consumers based on energy-related behavioral characteristics. Energy Policy 2011, 39, 8137-8152. [CrossRef]

9. Cuesta, M.A.; Castillo-Calzadilla, T.; Borges, C.E. A critical analysis on hybrid renewable energy modeling tools: An emerging opportunity to include social indicators to optimise systems in small communities. Renew. Sustain. Energy Rev. 2020, $122,109691$. [CrossRef] 
10. Colla, M.; Ioannou, A.; Falcone, G. Critical review of competitiveness indicators for energy projects. Renew. Sustain. Energy Rev. 2020, 125, 109794. [CrossRef]

11. Keirstead, J.; Jennings, M.; Sivakumar, A. A review of urban energy system models: Approaches, challenges and opportunities. Renew. Sustain. Energy Rev. 2012, 16, 3847-3866. [CrossRef]

12. Rae, C.; Bradley, F. Energy autonomy in sustainable communities-A review of key issues. Renew. Sustain. Energy Rev. 2012, 16, 6497-6506. [CrossRef]

13. Agency, I.E. World Energy Outlook 2020; OECD Publishing: Paris, France, 2020; p. 464. [CrossRef]

14. Tröndle, T.; Lilliestam, J.; Marelli, S.; Pfenninger, S. Trade-Offs between Geographic Scale, Cost, and Infrastructure Requirements for Fully Renewable Electricity in Europe. Joule 2020, 4, 1929-1948. [CrossRef]

15. Khalili, S.; Rantanen, E.; Bogdanov, D.; Breyer, C. Global Transportation Demand Development with Impacts on the Energy Demand and Greenhouse Gas Emissions in a Climate-Constrained World. Energies 2019, 12, 3870. [CrossRef]

16. Will, C.; Schuller, A. Understanding user acceptance factors of electric vehicle smart charging. Transp. Res. Part C Emerg. Technol. 2016, 71, 198-214. [CrossRef]

17. Bailey, J.; Axsen, J. Anticipating PEV buyers' acceptance of utility controlled charging. Transp. Res. Part A Policy Pract. 2015, 82, 29-46. [CrossRef]

18. Ensslen, A.; Ringler, P.; Dörr, L.; Jochem, P.; Zimmermann, F.; Fichtner, W. Incentivizing smart charging: Modeling charging tariffs for electric vehicles in German and French electricity markets. Energy Res. Soc. Sci. 2018, 42, 112-126. [CrossRef]

19. Emmerich, P.; Hülemeier, A.G.; Jendryczko, D.; Baumann, M.J.; Weil, M.; Baur, D. Public acceptance of emerging energy technologies in context of the German energy transition. Energy Policy 2020, 142, 111516. [CrossRef]

20. Wüstenhagen, R.; Wolsink, M.; Bürer, M.J. Social acceptance of renewable energy innovation: An introduction to the concept Energy Policy 2007, 35, 2683-2691. [CrossRef]

21. Sovacool, B.K. Experts, theories, and electric mobility transitions: Toward an integrated conceptual framework for the adoption of electric vehicles. Energy Res. Soc. Sci. 2017, 27, 78-95. [CrossRef]

22. Bertsch, V.; Hall, M.; Weinhardt, C.; Fichtner, W. Public acceptance and preferences related to renewable energy and grid expansion policy: Empirical insights for Germany. Energy 2016, 114, 465-477. [CrossRef]

23. Wolsink, M. Social acceptance revisited: Gaps, questionable trends, and an auspicious perspective. Energy Res. Soc. Sci. 2018, 46, 287-295. [CrossRef]

24. Schweizer-Ries, P. Energy sustainable communities: Environmental psychological investigations. Energy Policy 2008, 36, 4126-4135. [CrossRef]

25. Kleijnen, M.; Lee, N.; Wetzels, M. An exploration of consumer resistance to innovation and its antecedents. J. Econ. Psychol. 2009, 30, 344-357. [CrossRef]

26. Rogers, E.M. Diffusion of Innovations, 3rd ed.; Free Press: New York, NY, USA, 1983.

27. Zweifel, P.; Praktiknjo, A.; Erdmann, G. Energy Economics: Theory and Applications; Springer: Berlin/Heidelberg, Germany, 2017.

28. Möst, D.; Fichtner, W.; Grunwald, A. (Eds.) Energiesystemanalyse: Tagungsband des Workshops "Energiesystemanalyse" vom 27. November 2008 am KIT Zentrum Energie, Karlsruhe; KIT Scientific Publishing: Karslruhe, Germany, 2009. [CrossRef]

29. Lund, H.; Arler, F.; Østergaard, P.A.; Hvelplund, F.; Connolly, D.; Mathiesen, B.V.; Karnøe, P. Simulation versus Optimisation: Theoretical Positions in Energy System Modelling. Energies 2017, 10, 840. [CrossRef]

30. Hall, L.M.; Buckley, A.R. A review of energy systems models in the UK: Prevalent usage and categorisation. Appl. Energy 2016, 169, 607-628. [CrossRef]

31. Connolly, D.; Lund, H.; Mathiesen, B.V.; Leahy, M. A review of computer tools for analysing the integration of renewable energy into various energy systems. Appl. Energy 2010, 87, 1059-1082. [CrossRef]

32. Ringkjøb, H.K.; Haugan, P.M.; Solbrekke, I.M. A review of modelling tools for energy and electricity systems with large shares of variable renewables. Renew. Sustain. Energy Rev. 2018, 96, 440-459. [CrossRef]

33. Helistö, N.; Kiviluoma, J.; Holttinen, H.; Lara, J.D.; Hodge, B.M. Including operational aspects in the planning of power systems with large amounts of variable generation: A review of modeling approaches. Wiley Interdiscip. Rev. Energy Environ. 2019,8 , e341. [CrossRef]

34. Senkpiel, C.; Dobbins, A.; Kockel, C.; Steinbach, J.; Fahl, U.; Wille, F.; Globisch, J.; Wassermann, S.; Droste-Franke, B.; Hauser, W.; et al. Integrating Methods and Empirical Findings from Social and Behavioural Sciences into Energy System Models-Motivation and Possible Approaches. Energies 2020, 13, 4951. [CrossRef]

35. Richstein, J.C. Openmod: Open Energy Modelling Initiative; Richstein: Delft, The Netherlands, 2021. Available online: https: / / openmod-initiative.org/ (accessed on 26 July 2021).

36. Schrattenholzer, L. The energy supply model MESSAGE. Eur. J. Oper. Res. 1983, 12, 408. [CrossRef]

37. Fishbone, L.G.; Abilock, H. Markal, a linear-programming model for energy systems analysis: Technical description of the bnl version. Int. J. Energy Res. 1981, 5, 353-375. [CrossRef]

38. Loulou, R.; Labriet, M. ETSAP-TIAM: The TIMES integrated assessment model Part I: Model structure. Comput. Manag. Sci. 2008, 5, 7-40. [CrossRef]

39. Lopion, P.; Markewitz, P.; Robinius, M.; Stolten, D. A review of current challenges and trends in energy systems modeling. Renew. Sustain. Energy Rev. 2018, 96, 156-166. [CrossRef] 
40. Hörsch, J.; Hofmann, F.; Schlachtberger, D.; Brown, T. PyPSA-Eur: An open optimisation model of the European transmission system. Energy Strategy Rev. 2018, 22, 207-215. [CrossRef]

41. Helistö, N.; Kiviluoma, J.; Ikäheimo, J.; Rasku, T.; Rinne, E.; O’Dwyer, C.; Li, R.; Flynn, D. Backbone-An Adaptable Energy Systems Modelling Framework. Energies 2019, 12, 3388. [CrossRef]

42. Gabrielli, P.; Fürer, F.; Mavromatidis, G.; Mazzotti, M. Robust and optimal design of multi-energy systems with seasonal storage through uncertainty analysis. Appl. Energy 2019, 238, 1192-1210. [CrossRef]

43. Martinez Cesena, E.A.; Mancarella, P. Energy Systems Integration in Smart Districts: Robust Optimisation of Multi-Energy Flows in Integrated Electricity, Heat and Gas Networks. IEEE Trans. Smart Grid 2019, 10, 1122-1131. [CrossRef]

44. Mavromatidis, G.; Orehounig, K.; Carmeliet, J. Uncertainty and global sensitivity analysis for the optimal design of distributed energy systems. Appl. Energy 2018, 214, 219-238. [CrossRef]

45. Mavromatidis, G.; Orehounig, K.; Carmeliet, J. A review of uncertainty characterisation approaches for the optimal design of distributed energy systems. Renew. Sustain. Energy Rev. 2018, 88, 258-277. [CrossRef]

46. Mavromatidis, G.; Orehounig, K.; Carmeliet, J. Design of distributed energy systems under uncertainty: A two-stage stochastic programming approach. Appl. Energy 2018, 222, 932-950. [CrossRef]

47. Mundaca, L.; Neij, L.; Worrell, E.; McNeil, M. Evaluating Energy Efficiency Policies with Energy-Economy Models. Annu. Rev. Environ. Resour. 2010, 35, 305-344. [CrossRef]

48. Gabriel, S.A.; Kydes, A.S.; Whitman, P. The National Energy Modeling System: A Large-Scale Energy-Economic Equilibrium Model. Oper. Res. 2001, 49, 14-25. [CrossRef]

49. e3mlab. The PRIMES Energy System Model. 2008. Available online: http://www.e3mlab.eu/e3mlab/PRIMES\%20Manual/ PRIMsd.pdf (accessed on 27 July 2021).

50. Bolwig, S.; Bazbauers, G.; Klitkou, A.; Lund, P.D.; Blumberga, A.; Gravelsins, A.; Blumberga, D. Review of modelling energy transitions pathways with application to energy system flexibility. Renew. Sustain. Energy Rev. 2019, 101, 440-452. [CrossRef]

51. Black, J.S.; Stern, P.C.; Elworth, J.T. Personal and contextual influences on househould energy adaptations. J. Appl. Psychol. 1985, 70, 3. [CrossRef]

52. Guagnano, G.A.; Stern, P.C.; Dietz, T. Influences on attitude-behavior relationships a natural experiment with curbside recycling. Environ. Behav. 1995, 27, 699-718. [CrossRef]

53. Fishbein, M.; Ajzen, I. Belief, Attitude, Intention, and Behavior: An Introduction to Theory and Research; Addison-Wesley: Reading, MA, USA, 1975.

54. Ajzen, I.; Fishbein, M. Attitude-behavior relations: A theoretical analysis and review of empirical research. Psychol. Bull. 1977, 84, 888. [CrossRef]

55. Ajzen, I. From intentions to actions: A theory of planned behavior. In Action Control; Springer: Berlin/Heidelberg, Germany, 1985; pp. 11-39.

56. Venkatesh, V.; Morris, M.G.; Davis, G.B.; Davis, F.D. User Acceptance of Information Technology: Toward a Unified View. MIS Q. 2003, 27, 425-478. [CrossRef]

57. Davis, F.D.; Bagozzi, R.P.; Warshaw, P.R. User acceptance of computer technology: A comparison of two theoretical models. Manag. Sci. 1989, 35, 982-1003. [CrossRef]

58. Devine-Wright, P. Reconsidering Public Attitudes and Public Acceptance of Renewable Energy Technologies: A Critical Review: Working Paper 1.4. 2007. Available online: https://geography.exeter.ac.uk/beyond_nimbyism/deliverables/bn_wp1_4.pdf (accessed on 27 July 2021).

59. Cohen, J.; Moeltner, K.; Reichl, J.; Schmidthaler, M. An empirical analysis of local opposition to new transmission lines across the EU-27. Energy J. 2016, 37, 59-82 [CrossRef]

60. Vorkinn, M.; Riese, H. Environmental concern in a local context: The significance of place attachment. Environ. Behav. 2001, 33, 249-263. [CrossRef]

61. Dietz, T.; Stern, P.C.; Guagnano, G.A. Social structural and social psychological bases of environmental concern. Environ. Behav. 1998, 30, 450-471. [CrossRef]

62. Bidwell, D. The role of values in public beliefs and attitudes towards commercial wind energy. Energy Policy 2013, 58, 189-199. [CrossRef]

63. Devine-Wright, P.; Batel, S. Explaining public preferences for high voltage pylon designs: An empirical study of perceived fit in a rural landscape. Land Use Policy 2013, 31, 640-649. [CrossRef]

64. Anton, C.E.; Lawrence, C. Home is where the heart is: The effect of place of residence on place attachment and community participation. J. Environ. Psychol. 2014, 40, 451-461. [CrossRef]

65. Devine-Wright, P. Explaining "NIMBY" objections to a power line: The role of personal, place attachment and project-related factors. Environ. Behav. 2012, 45, 761-781. [CrossRef]

66. Bertsch, V.; Hyland, M.; Mahony, M. What drives people's opinions of electricity infrastructure? Empirical evidence from Ireland. Energy Policy 2017, 106, 472-497. [CrossRef]

67. Wolsink, M. Wind power and the NIMBY-myth: Institutional capacity and the limited significance of public support. Renew. Energy 2000, 21, 49-64. [CrossRef]

68. SEI. Attitudes towards the development of wind farms in Ireland. Sustain. Energy Ireland 2003. Available online: https://mosart. ie/wp-content/uploads/2016/02/Attitudes-Towards-Wind-Farm-Development-Ireland.pdf (accessed on 26 July 2021). 
69. Nadaï, A.; Van Der Horst, D. Wind power planning, landscapes and publics. Land Use Policy 2010 27, 181-184 [CrossRef]

70. Cotton, M.; Devine-Wright, P. Discourses of energy infrastructure development: A Q-method study of electricity transmission line siting in the UK. Environ. Plan. A 2011, 43, 942-960. [CrossRef]

71. Warren, C.R.; Lumsden, C.; O'Dowd, S.; Birnie, R.V. 'Green on green': Public perceptions of wind power in Scotland and Ireland. J. Environ. Plan. Manag. 2005, 48, 853-875. [CrossRef]

72. Ansolabehere, S.; Konisky, D.M. Public attitudes toward construction of new power plants. Public Opin. Q. 2009, 73, 566-577. [CrossRef]

73. Poortinga, W.; Pidgeon, N.; Lorenzoni, I. Public Perceptions of Nuclear Power, Climate Change and Energy Options in Britain: Summary Findings of a Survey Conducted during October and November 2005; Technical Report (Understanding Risk Working Paper 06-02); Centre for Environmental Risk: Norwich, UK, 2006.

74. Soini, K.; Pouta, E.; Salmiovirta, M.; Uusitalo, M.; Kivinen, T. Local residents' perceptions of energy landscape: The case of transmission lines. Land Use Policy 2011, 28, 294-305. [CrossRef]

75. Upham, P.; Shackley, S. The case of a proposed 21.5 MWe biomass gasifier in Winkleigh, Devon: Implications for governance of renewable energy planning. Energy Policy 2006, 34, 2161-2172. [CrossRef]

76. Van Rensburg, T.M.; Kelley, H.; Jeserich, N. What influences the probability of wind farm planning approval: Evidence from Ireland. Ecol. Econ. 2015, 111, 12-22. [CrossRef]

77. Jones, C.R.; Richard Eiser, J. Understanding 'local' opposition to wind development in the UK: How big is a backyard? Energy Policy 2010. 38, 3106-3117. [CrossRef]

78. Brennan, N.; Van Rensburg, T.M. Wind farm externalities and public preferences for community consultation in Ireland: A discrete choice experiments approach. Energy Policy 2016. 94, 355-365 [CrossRef]

79. Mueller, C.E.; Keil, S.I.; Bauer, C. Effects of spatial proximity to proposed high-voltage transmission lines: Evidence from a natural experiment in Lower Saxony. Energy Policy 2017, 111, 137-147. [CrossRef]

80. Harold, J.; Bertsch, V.; Lawrence, T.; Hall, M. Drivers of people's preferences for spatial proximity to energy infrastructure technologies: A cross-country analysis. Energy J. 2021, 42, 47-89. [CrossRef]

81. Rand, J.; Hoen, B. Thirty years of North American wind energy acceptance research: What have we learned? Energy Res. Soc. Sci. 2017, 29, 135-148. [CrossRef]

82. Guo, Y.; Ru, P.; Su, J.; Anadon, L.D. Not in my backyard, but not far away from me: Local acceptance of wind power in China. Energy 2015, 82, 722-733. [CrossRef]

83. Carlisle, J.E.; Solan, D.; Kane, S.L.; Joe, J. Utility-scale solar and public attitudes toward siting: A critical examination of proximity. Land Use Policy 2016. 58, 491-501. [CrossRef]

84. Betakova, V.; Vojar, J.; Sklenicka, P. Wind turbines location: How many and how far? Appl. Energy 2015, 151, 23-31. [CrossRef]

85. Brennan, N.; Van Rensburg, T.M.; Morris, C. Public acceptance of large-scale wind energy generation for export from Ireland to the UK: Evidence from Ireland. J. Environ. Plan. Manag. 2017, 60, 1967-1992. [CrossRef]

86. Devine-Wright, P. Beyond NIMBYism: Towards an integrated framework for understanding public perceptions of wind energy. Wind Energy 2005, 8, 125-139. [CrossRef]

87. Ladenburg, J.; Dahlgaard, J.O. Attitudes, threshold levels and cumulative effects of the daily wind-turbine encounters. Appl. Energy 2012, 98, 40-46. [CrossRef]

88. Molnarova, K.; Sklenicka, P.; Stiborek, J.; Svobodova, K.; Salek, M.; Brabec, E. Visual preferences for wind turbines: Location, numbers and respondent characteristics. Appl. Energy 2012, 92, 269-278. [CrossRef]

89. Strachan, P.A.; Cowell, R.; Ellis, G.; Sherry-Brennan, F.; Toke, D. Promoting Community Renewable Energy in a Corporate Energy World. Sustain. Dev. 2015, 23, 96-109. [CrossRef]

90. Wolsink, M. Attitudes and Expectancies about Wind Turbines and Wind Farms. Wind Eng. 1989, 13, $196-206$.

91. Tsoutsos, T.; Tsouchlaraki, A.; Tsiropoulos, M.; Serpetsidakis, M. Visual impact evaluation of a wind park in a Greek island. Appl. Energy 2009. 86, 546-553. [CrossRef]

92. Stern, P.C.; Dietz, T.; Guagnano, G.A. The new ecological paradigm in social-psychological context. Environ. Behav. 1995, 27, 723-743. [CrossRef]

93. Poortinga, W.; Spence, A.; Whitmarsh, L.; Capstick, S.; Pidgeon, N.F. Uncertain climate: An investigation into public scepticism about anthropogenic climate change. Glob. Environ. Chang. 2011, 21, 1015-1024. [CrossRef]

94. Populus. Energy Balance of Power Poll. 2005. Available online: http://www.populus.co.uk/poll/energy-balance-of-power/ (accessed on 26 July 2021).

95. Zoellner, J.; Ittner, H.; Schweizer-Ries, P. Perceived procedural justice as a conflict factor in wind energy plants planning processes. In Proceedings of the Fifth BIEE Academic Conference: “European Energy-Synergies and Conflicts”, Oxford, UK, 22-23 September 2005.

96. Aitken, M. Why we still don't understand the social aspects of wind power: A critique of key assumptions within the literature. Energy Policy 2010, 38, 1834-1841. [CrossRef]

97. Terwel, B.W.; Harinck, F.; Ellemers, N.; Daamen, D.D. Going beyond the properties of CO2 capture and storage (CCS) technology: How trust in stakeholders affects public acceptance of CCS. Int. J. Greenh. Gas Control 2011, 5, 181-188. [CrossRef]

98. Huijts, N.M.A.; Molin, E.J.E.; Steg, L. Psychological factors influencing sustainable energy technology acceptance: A review-based comprehensive framework. Renew. Sustain. Energy Rev. 2012, 16, 525-531. [CrossRef] 
99. Ciupuliga, A.; Cuppen, E. The role of dialogue in fostering acceptance of transmission lines: the case of a France-Spain interconnection project. Energy Policy 2013, 60, 224-233. [CrossRef]

100. Aaen, S.B.; Kerndrup, S.; Lyhne, I. Beyond public acceptance of energy infrastructure: How citizens make sense and form reactions by enacting networks of entities in infrastructure development. Energy Policy 2016, 96, 576-586. [CrossRef]

101. Butkowski, O.K.; Baum, C.M.; Pakseresht, A.; Bröring, S.; Lagerkvist, C.J. Examining the social acceptance of genetically modified bioenergy in Germany: Labels, information valence, corporate actors, and consumer decisions. Energy Res. Soc. Sci. 2020, 60, 101308. [CrossRef]

102. Caporale, D.; Sangiorgio, V.; Amodio, A.; de Lucia, C. Multi-criteria and focus group analysis for social acceptance of wind energy. Energy Policy 2020, 140, 111387. [CrossRef]

103. Bögel, P.; Oltra, C.; Sala, R.; Lores, M.; Upham, P.; Dütschke, E.; Schneider, U.; Wiemann, P. The role of attitudes in technology acceptance management: Reflections on the case of hydrogen fuel cells in Europe. J. Clean. Prod. 2018, 188, 125-135. [CrossRef]

104. Toke, D. Wind power in UK and Denmark: Can rational choice help explain different outcomes? Environ. Politics 2002, 11, 83-100. [CrossRef]

105. Bauwens, T.; Gotchev, B.; Holstenkamp, L. What drives the development of community energy in Europe? The case of wind power cooperatives. Energy Res. Soc. Sci. 2016, 13, 136-147. [CrossRef]

106. Schreuer, A. The establishment of citizen power plants in Austria: A process of empowerment? Energy Res. Soc. Sci. 2016, 13, 126-135. [CrossRef]

107. Shamon, H.; Schumann, D.; Fischer, W.; Vögele, S.; Heinrichs, H.U.; Kuckshinrichs, W. Changing attitudes and conflicting arguments: Reviewing stakeholder communication on electricity technologies in Germany. Energy Res. Soc. Sci. 2019, 55, 106-121. [CrossRef]

108. Belaïd, F.; Joumni, H. Behavioral attitudes towards energy saving: Empirical evidence from France. Energy Policy 2020, $140,111406$. [CrossRef]

109. Adnan, N.; Nordin, S.M.; Rahman, I.; Vasant, P.M.; Noor, A. A comprehensive review on theoretical framework-based electric vehicle consumer adoption research. Int. J. Energy Res. 2017, 41, 317-335. [CrossRef]

110. Barbarossa, C.; Beckmann, S.C.; de Pelsmacker, P.; Moons, I.; Gwozdz, W. A self-identity based model of electric car adoption intention: A cross-cultural comparative study. J. Environ. Psychol. 2015, 42, 149-160. [CrossRef]

111. Wahl, L.S.; Hsiang, W.H.; Hauer, G. The Intention to Adopt Battery Electric Vehicles in Germany: Driven by Consumer Expectancy, Social Influence, Facilitating Conditions and Ecological Norm Orientation. In Innovations for Metropolitan Areas; Planing, P., Müller, P., Dehdari, P.; Bäumer, T., Eds.; Springer: Berlin/Heidelberg, Germany, 2020; pp. 79-92.

112. Shalender, K.; Sharma, N. Using extended theory of planned behaviour (TPB) to predict adoption intention of electric vehicles in India. Environ. Dev. Sustain. 2021, 23, 665-681. [CrossRef]

113. McCoy, D.; Lyons, S. Consumer preferences and the influence of networks in electric vehicle diffusion: An agent-based microsimulation in Ireland. Energy Res. Soc. Sci. 2014, 3, 89-101. [CrossRef]

114. Ensslen, A.; Will, C.; Jochem, P. Simulating Electric Vehicle Diffusion and Charging Activities in France and Germany. World Electr. Veh. J. 2019, 10, 73. [CrossRef]

115. Bass, F.M. A new product growth for model consumer durables. Manag. Sci. 1969, 15, 215-227. [CrossRef]

116. Kühl, N.; Goutier, M.; Ensslen, A.; Jochem, P. Literature vs. Twitter: Empirical insights on customer needs in e-mobility. J. Clean. Prod. 2019, 213, 508-520. [CrossRef]

117. Aravena, C.; Riquelme, A.; Denny, E. Money, comfort or environment? Priorities and determinants of energy efficiency investments in Irish households. J. Consum. Policy 2016, 39, 159-186. [CrossRef]

118. Curtis, J.; McCoy, D.; Aravena, C. Heating system upgrades: The role of knowledge, socio-demographics, building attributes and energy infrastructure. Energy Policy 2018, 120, 183-196. [CrossRef]

119. Heiskanen, E.; Matschoss, K. Understanding the uneven diffusion of building-scale renewable energy systems: A review of household, local and country level factors in diverse European countries. Renew. Sustain. Energy Rev. 2017, 75, 580-591. [CrossRef]

120. Scheller, F.; Doser, I.; Sloot, D.; McKenna, R.; Bruckner, T. Exploring the Role of Stakeholder Dynamics in Residential Photovoltaic Adoption Decisions: A Synthesis of the Literature. Energies 2020, 13, 6283. [CrossRef]

121. Willis, K.; Scarpa, R.; Gilroy, R.; Hamza, N. Renewable energy adoption in an ageing population: Heterogeneity in preferences for micro-generation technology adoption. Energy Policy 2011, 39, 6021-6029. [CrossRef]

122. Balcombe, P.; Rigby, D.; Azapagic, A. Motivations and barriers associated with adopting microgeneration energy technologies in the UK. Renew. Sustain. Energy Rev. 2013, 22, 655-666. [CrossRef]

123. Yamamoto, Y. Opinion leadership and willingness to pay for residential photovoltaic systems. Energy Policy 2015, 83, 185-192. [CrossRef]

124. Ropuszyńska-Surma, E.; Węglarz, M. The Behavioural Profiles of Energy Consumers: Comparison of the Decision Tree Method and the Logit Model. In Perspectives on Consumer Behaviour; Springer: Berlin/Heidelberg, Germany, 2020; pp. 211-239.

125. Sarfarazi, S.; Deissenroth-Uhrig, M.; Bertsch, V. Aggregation of Households in Community Energy Systems: An Analysis from Actors' and Market Perspectives. Energies 2020, 13, 5154. [CrossRef]

126. Müller, M.O.; Stämpfli, A.; Dold, U.; Hammer, T. Energy autarky: A conceptual framework for sustainable regional development. Energy Policy 2011, 39, 5800-5810. [CrossRef] 
127. Balcombe, P.; Rigby, D.; Azapagic, A. Energy self-sufficiency, grid demand variability and consumer costs: Integrating solar PV, Stirling engine CHP and battery storage. Appl. Energy 2015, 155, 393-408. [CrossRef]

128. Bertsch, V.; Geldermann, J.; Lühn, T. What drives the profitability of household PV investments, self-consumption and selfsufficiency? Appl. Energy 2017, 204, 1-15. [CrossRef]

129. Schwarz, H.; Schermeyer, H.; Bertsch, V.; Fichtner, W. Self-consumption through power-to-heat and storage for enhanced PV integration in decentralised energy systems. Sol. Energy 2018, 163, 150-161. [CrossRef]

130. Schweizer, P.J.; Bovet, J. The potential of public participation to facilitate infrastructure decision-making: Lessons from the German and European legal planning system for electricity grid expansion. Utilities Policy 2016, 42, 64-73. [CrossRef]

131. Liebe, U.; Bartczak, A.; Meyerhoff, J. A turbine is not only a turbine: The role of social context and fairness characteristics for the local acceptance of wind power. Energy Policy 2017, 107, 300-308. [CrossRef]

132. Renn, O.; Ulmer, F.; Deckert, A. The Role of Public Participation in Energy Transitions; Academic Press: Cambridge, MA, USA, 2020.

133. Devine-Wright, P. Local aspects of UK renewable energy development: Exploring public beliefs and policy implications. Local Environ. 2005, 10, 57-69. [CrossRef]

134. Devine-Wright, P. Community versus local energy in a context of climate emergency. Nat. Energy 2019, 4, 894-896. [CrossRef]

135. Schumacher, K.; Krones, F.; McKenna, R.; Schultmann, F. Public acceptance of renewable energies and energy autonomy: A comparative study in the French, German and Swiss Upper Rhine region. Energy Policy 2019, 126, 315-332. [CrossRef]

136. Engelken, M.; Römer, B.; Drescher, M.; Welpe, I. Transforming the energy system: Why municipalities strive for energy self-sufficiency. Energy Policy 2016, 98, 365-377. [CrossRef]

137. Hicks, J.; Ison, N. Community-owned renewable energy (CRE): Opportunities for rural Australia. Rural Soc. 2011, 20, $244-255$. [CrossRef]

138. Burke, M.J.; Stephens, J.C. Energy democracy: Goals and policy instruments for sociotechnical transitions. Energy Res. Soc. Sci. 2017, 33, 35-48. [CrossRef]

139. Di Silvestre, M.L.; Favuzza, S.; Riva Sanseverino, E.; Zizzo, G. How Decarbonization, Digitalization and Decentralization are changing key power infrastructures. Renew. Sustain. Energy Rev. 2018, 93, 483-498. [CrossRef]

140. Romanchenko, D.; Nyholm, E.; Odenberger, M.; Johnsson, F. Impacts of demand response from buildings and centralized thermal energy storage on district heating systems. Sustain. Cities Soc. 2021, 64, 102510. [CrossRef]

141. Laicane, I.; Blumberga, D.; Blumberga, A.; Rosa, M. Reducing Household Electricity Consumption through Demand Side Management: The Role of Home Appliance Scheduling and Peak Load Reduction. Energy Procedia 2015, 72, 222-229. [CrossRef]

142. Zehir, M.A.; Bagriyanik, M. Demand Side Management by controlling refrigerators and its effects on consumers. Energy Convers. Manag. 2012, 64, 238-244. [CrossRef]

143. Brazil, W.; Harold, J.; Curtis, J.A. The Role of Socio-Economic Characteristics in Predicting Peak Period Appliance Use; Technical report, ESRI Working Paper; The Economic and Social Research Institute (ESRI): Dublin, Ireland, 2019

144. Nolan, S.; O'Malley, M. Challenges and barriers to demand response deployment and evaluation. Appl. Energy 2015, 152, 1-10. [CrossRef]

145. Faruqui, A.; Sergici, S. Household response to dynamic pricing of electricity: A survey of 15 experiments. J. Regul. Econ. 2010, 38, 193-225. [CrossRef]

146. Di Cosmo, V.; Lyons, S.; Nolan, A. Estimating the impact of time-of-use pricing on Irish electricity demand. Energy J. 2014, 35, 117-136 [CrossRef]

147. Broberg, T.; Persson, L. Is our everyday comfort for sale? Preferences for demand management on the electricity market. Energy Econ. 2016, 54, 24-32. [CrossRef]

148. Harold, J.; Bertsch, V.; Fell, H. Preferences for curtailable electricity contracts: Can curtailment benefit consumers and the electricity system? Energy Econ. 2021, 105454. [CrossRef]

149. Curtis, J.; Grilli, G.; Brazil, W.; Harold, J. Why do preferences for electricity services differ? Domestic appliance curtailment contracts in Ireland. Energy Res. Soc. Sci. 2020, 69, 101705. [CrossRef]

150. Frondel, M. Empirical assessment of energy-price policies: The case for cross-price elasticities. Energy Policy 2004, 32, 989-1000. [CrossRef]

151. Frondel, M. Modelling energy and non-energy substitution: A brief survey of elasticities. Energy Policy 2011, 39, 4601-4604. [CrossRef]

152. Kirschen, D.S.; Strbac, G. Fundamentals of Power System Economics; John Wiley \& Sons: Hoboken, NJ, USA, 2018.

153. Van der Welle, A.; Van der Zwaan, B. An Overview of Selected Studies on the Value of Lost Load (VOLL), Energy research Centre of the Netherlands (ECN): Working Paper 2007. Available online http:/ /www.transust.org/workplan/papers/wp2_task_ 5_lost_load.pdf (accessed on 26 July 2021).

154. Leahy, E.; Tol, R.S. An estimate of the value of lost load for Ireland. Energy Policy 2011, 39, 1514-1520. [CrossRef]

155. Praktiknjo, A.J. Stated preferences based estimation of power interruption costs in private households: An example from Germany. Energy 2014, 76, 82-90. [CrossRef]

156. Schröder, T.; Kuckshinrichs, W. Value of lost load: An efficient economic indicator for power supply security? A literature review. Front. Energy Res. 2015, 3, 55. [CrossRef]

157. Fitiwi, D.Z.; Lynch, M.; Bertsch, V. Power system impacts of community acceptance policies for renewable energy deployment under storage cost uncertainty. Renew. Energy 2020, 156, 893-912. [CrossRef] 
158. Koecklin, M.T.; Longoria, G.; Fitiwi, D.Z.; DeCarolis, J.F.; Curtis, J. Public acceptance of renewable electricity generation and transmission network developments: Insights from Ireland. Energy Policy 2021, 151, 112185. [CrossRef]

159. Freeman, L.C. A Set of Measures of Centrality Based on Betweenness. Sociometry 1977, 40, 35. [CrossRef]

160. Rose, M.E.; Kitchin, J.R. pybliometrics: Scriptable bibliometrics using a Python interface to Scopus. SoftwareX $2019,10,100263$. [CrossRef]

161. Hagberg, A.A.; Schult, D.A.; Swart, P.J. Exploring Network Structure, Dynamics, and Function using NetworkX. In Proceedings of the 7th Python in Science Conference, Pasadena, CA, USA, 19-24 August 2008; Varoquaux, G., Vaught, T., Millman, J., Eds.; SciPy: Pasadena, CA, USA; 2008; pp. 11-15

162. Wapman, K.; Larremore, D. webweb: A tool for creating, displaying, and sharing interactive network visualizations on the web. J. Open Source Softw. 2019, 4, 1458. [CrossRef]

163. Østergaard, P.A. Reviewing optimisation criteria for energy systems analyses of renewable energy integration. Energy 2009, 34, 1236-1245. [CrossRef]

164. Bale, C.S.; Varga, L.; Foxon, T.J. Energy and complexity: New ways forward. Appl. Energy 2015, 138, 150-159. [CrossRef]

165. Blanco, H.; Nijs, W.; Ruf, J.; Faaij, A. Potential for hydrogen and Power-to-Liquid in a low-carbon EU energy system using cost optimization. Appl. Energy 2018, 232, 617-639. [CrossRef]

166. Bolwig, S.; Bolkesjø, T.F.; Klitkou, A.; Lund, P.D.; Bergaentzlé, C.; Borch, K.; Olsen, O.J.; Kirkerud, J.G.; Chen, Y.K.; Gunkel, P.A.; et al. Climate-friendly but socially rejected energy-transition pathways: The integration of techno-economic and socio-technical approaches in the Nordic-Baltic region. Energy Res. Soc. Sci. 2020, 67, 101559. [CrossRef]

167. Wingenbach, M. Integration sozial-ökologischer Faktoren in die Energiesystemmodellierung: Am Beispiel von Entwicklungspfaden für den Windenergieausbau in Deutschland: Dissertation 2018. Available online: https: / www.baufachinformation.de/ integration-sozial-oekologischer-faktoren-in-die-energiesystemmodellierung-am-beispiel-von-entwicklungspfaden-fuer-denwindenergieausbau-in-deutschland/bu/2019099005979 (accessed on 26 July 2021).

168. McKenna, R.; Bertsch, V.; Mainzer, K.; Fichtner, W. Combining local preferences with multi-criteria decision analysis and linear optimization to develop feasible energy concepts in small communities. Eur. J. Oper. Res. 2018, 268, 1092-1110. [CrossRef]

169. Ghatikar, G.; Mashayekh, S.; Stadler, M.; Yin, R.; Liu, Z. Distributed energy systems integration and demand optimization for autonomous operations and electric grid transactions. Appl. Energy 2016, 167, 432-448. [CrossRef]

170. Steffen, B. The importance of project finance for renewable energy projects. Energy Econ. 2018, 69, 280-294. [CrossRef]

171. Hahnel, U.J.; Herberz, M.; Pena-Bello, A.; Parra, D.; Brosch, T. Becoming prosumer: Revealing trading preferences and decision-making strategies in peer-to-peer energy communities. Energy Policy 2020, 137, 111098. [CrossRef]

172. Pye, S.; Daly, H. Modelling sustainable urban travel in a whole systems energy model. Appl. Energy 2015, 159, 97-107. [CrossRef]

173. Daly, H.E.; Ramea, K.; Chiodi, A.; Yeh, S.; Gargiulo, M.; Ó Gallachóir, B. Modal Shift of Passenger Transport in a TIMES Model: Application to Ireland and California. In Informing Energy and Climate Policies Using Energy Systems Models; Giannakidis, G., Labriet, M., Ó Gallachóir, B., Tosato, G., Eds.; Lecture Notes in Energy; Springer International Publishing: Cham, Switzerland, 2015; Volume 30, pp. 279-291. [CrossRef]

174. Steinbach, J. Modellbasierte Untersuchung von Politikinstrumenten zur Förderung erneuerbarer Energien und Energieeffizienz im Gebäudebereich. Dissertation, Fraunhofer-Institut für System- und Innovationsforschung. 2015. Available online: http: / / publica.fraunhofer.de/dokumente/N-385554.html (accessed on 26 July 2021).

175. Kowalska-Pyzalska, A.; Maciejowska, K.; Suszczyński, K.; Sznajd-Weron, K.; Weron, R. Turning green: Agent-based modeling of the adoption of dynamic electricity tariffs. Energy Policy 2014, 72, 164-174. [CrossRef]

176. Collaço, F.M.d.A.; Simoes, S.G.; Dias, L.P.; Duic, N.; Seixas, J.; Bermann, C. The dawn of urban energy planning - Synergies between energy and urban planning for São Paulo (Brazil) megacity. J. Clean. Prod. 2019, 215, 458-479. [CrossRef]

177. Bai, L.; Li, F.; Cui, H.; Jiang, T.; Sun, H.; Zhu, J. Interval optimization based operating strategy for gas-electricity integrated energy systems considering demand response and wind uncertainty. Appl. Energy 2016, 167, 270-279. [CrossRef]

178. Strachan, N.; Kannan, R. Hybrid modelling of long-term carbon reduction scenarios for the UK. Energy Econ. 2008, 30, $2947-2963$. [CrossRef]

179. Rastegar, M.; Fotuhi-Firuzabad, M.; Lehtonen, M. Home load management in a residential energy hub. Electr. Power Syst. Res. 2015, 119, 322-328. [CrossRef]

180. Atia, R.; Yamada, N. Sizing and Analysis of Renewable Energy and Battery Systems in Residential Microgrids. IEEE Trans. Smart Grid 2016, 7, 1204-1213. [CrossRef]

181. Anvari-Moghaddam, A.; Rahimi-Kian, A.; Mirian, M.S.; Guerrero, J.M. A multi-agent based energy management solution for integrated buildings and microgrid system. Appl. Energy 2017, 203, 41-56. [CrossRef]

182. Good, N.; Zhang, L.; Navarro-Espinosa, A.; Mancarella, P. High resolution modelling of multi-energy domestic demand profiles. Appl. Energy 2015, 137, 193-210. [CrossRef]

183. Bustos-Turu, G.; van Dam, K.H.; Acha, S.; Markides, C.N.; Shah, N. Simulating residential electricity and heat demand in urban areas using an agent-based modelling approach. In Proceedings of the 2016 IEEE International Energy Conference (ENERGYCON), Leuven, Belgium, 4-8 April 2016; pp. 1-6. [CrossRef]

184. Li, Y.; Yang, W.; He, P.; Chen, C.; Wang, X. Design and management of a distributed hybrid energy system through smart contract and blockchain. Appl. Energy 2019, 248, 390-405. [CrossRef] 
185. Sheikhi, A.; Rayati, M.; Bahrami, S.; Mohammad Ranjbar, A. Integrated Demand Side Management Game in Smart Energy Hubs. IEEE Trans. Smart Grid 2015, 6, 675-683. [CrossRef]

186. Lee, Y.S.; Malkawi, A.M. Simulating multiple occupant behaviors in buildings: An agent-based modeling approach. Energy Build. 2014, 69, 407-416. [CrossRef]

187. Capellán-Pérez, I.; de Blas, I.; Nieto, J.; de Castro, C.; Miguel, L.J.; Carpintero, Ó.; Mediavilla, M.; Lobejón, L.F.; Ferreras-Alonso, N.; Rodrigo, P.; et al. MEDEAS: A new modeling framework integrating global biophysical and socioeconomic constraints. Energy Environ. Sci. 2020, 13, 986-1017. [CrossRef]

188. Li, F.G.; Strachan, N. Modelling energy transitions for climate targets under landscape and actor inertia. Environ. Innov. Soc. Transit. 2017, 24, 106-129. [CrossRef]

189. Li, F.G.; Trutnevyte, E.; Strachan, N. A review of socio-technical energy transition (STET) models. Technol. Forecast. Soc. Chang. 2015, 100, 290-305. [CrossRef]

190. Li, F.G.; Strachan, N. Take me to your leader: Using socio-technical energy transitions (STET) modelling to explore the role of actors in decarbonisation pathways. Energy Res. Soc. Sci. 2019, 51, 67-81. [CrossRef]

191. Sun, K.; Hong, T. A framework for quantifying the impact of occupant behavior on energy savings of energy conservation measures. Energy Build. 2017, 146, 383-396. [CrossRef]

192. Le Gallic, T.; Assoumou, E.; Maïzi, N. Future demand for energy services through a quantitative approach of lifestyles. Energy 2017, 141, 2613-2627. [CrossRef]

193. Foxon, T.J. A coevolutionary framework for analysing a transition to a sustainable low carbon economy. Ecol. Econ. 2011, 70, 2258-2267. [CrossRef]

194. Wittmann, T. Agent-Based Models of Energy Investment Decisions; Physica-Verlag HD: Heidelberg, Germany, 2008. [CrossRef]

195. Wang, J.J.; Jing, Y.Y.; Zhang, C.F.; Zhao, J.H. Review on multi-criteria decision analysis aid in sustainable energy decision-making. Renew. Sustain. Energy Rev. 2009, 13, 2263-2278. [CrossRef]

196. Bieber, N.; Ker, J.H.; Wang, X.; Triantafyllidis, C.; van Dam, K.H.; Koppelaar, R.H.; Shah, N. Sustainable planning of the energy-water-food nexus using decision making tools. Energy Policy 2018, 113, 584-607. [CrossRef]

197. Tu, G.; Faure, C.; Schleich, J.; Guetlein, M.C. The heat is off! The role of technology attributes and individual attitudes in the diffusion of Smart thermostats-findings from a multi-country survey. Technol. Forecast. Soc. Chang. 2021, 163, 120508. [CrossRef]

198. Schleich, J.; Faure, C.; Meissner, T. Adoption of retrofit measures among homeowners in EU countries: The effects of access to capital and debt aversion. Energy Policy 2021, 149, 112025. [CrossRef]

199. Cheetah, P.C. CHEETAH Final Publishable Report; Fraunhofer Institute for Systems and Innovation Research ISI: Karlsruhe, Germany, 2020.

200. Sopha, B.M.; Klöckner, C.A.; Hertwich, E.G. Adoption and diffusion of heating systems in Norway: Coupling agent-based modeling with empirical research. Environ. Innov. Soc. Transit. 2013, 8, 42-61. [CrossRef]

201. Devine, M.T.; Bertsch, V. Examining the benefits of load shedding strategies using a rolling-horizon stochastic mixed complementarity equilibrium model. Eur. J. Oper. Res. 2018, 267, 643-658. [CrossRef]

202. Böhringer, C.; Löschel, A. Computable general equilibrium models for sustainability impact assessment: Status quo and prospects. Ecol. Econ. 2006, 60, 49-64. [CrossRef]

203. Paltsev, S. Moving from Static to Dynamic General Equilibrium Economic Models (Notes for a Beginner in MPSGE).2008 Available online: http:/ / web.mit.edu/paltsev/www/docs/move04.html (accessed on 26 July 2021).

204. Patankar, N.; Fell, H.G.; Rodrigo de Queiroz, A.; Curtis, J.; DeCarolis, J.F. Improving the Representation of Energy Efficiency in an Energy System Optimization Model; Work in Progress, Princeton University: Princeton, NJ, USA, 2021.

205. Phillips, L.D. Decision conferencing. In IEE Colloquium on CSCW: Some Fundamental Issues; IET: London, UK, 1991

206. Phillips, L.D.; e Costa, C.A.B. Transparent prioritisation, budgeting and resource allocation with multi-criteria decision analysis and decision conferencing. Ann. Oper. Res. 2007, 154, 51-68. [CrossRef]

207. Stocker, T.F. Climate change. The closing door of climate targets. Science 2013, 339, 280-282. [CrossRef] [PubMed] 